THE FLORA OF THE CARBONIFEROUS PERIOD.

BY ROBERT KIDSTON, F.R.S., F.R.S.E., F.G.S.

\title{
SECOND PAPER.
}

In the first paper, the Ferns, Equisetites, and Calamites were dealt with ; in the present communication the Lycopodiacece, Sphenophyllea, Cordaitea, Coniferce, and Ginkgoacea will be shortly considered.

\section{LyCOPODLACE\&.}

Among the Carboniferous Lycopods a few are found of comparatively small size, perhaps not much larger than some exotic species of Selaginella, whilst others, like Lepidodendron, attained to arborescent dimensions.

No group of Carboniferous plants rises to the same importance as that of the Lycopodiaceæ. It comprises several genera and some of these contain many species.

The Lycopods must also have supplied much of the material from which our coal seams are formed. Their importance in this respect can be judged by the fact that it is of frequent occurrence to find in coal, bands of over half an inch in thickness formed entirely of Lycopod spores.

We shall now examine shortly the chief genera belonging to this group which occur in Britain.

\section{I.-LyCopoDite $x$.}

Lycopodites Brongniart. Members of the genus Lycopodites are very rare in Carboniferous times; only three species have come under my notice as British, and each has only been represented by a single specimen. One of these, Lycopodites ciliatus Kidston, is from Yorkshire and was collected by Mr. Hemingway.

The Lycopodites are all small and had whorled or spirally-placed leaves. In Lycopodites gutbieri Göpp. (Plate LXIV., fig. 1), for the 
KIDSTON: THE FLORA OF THE CARBONIFEROUS PERIOD.

size of the stem, the two lateral rows of leaves are large, single-nerved, and sickle-shaped, while the two ventral rows are very small and closely adpressed to the stem. Such types have a great resemblance to some forms of Selaginella. In other species the leaves appear to be whorled as in Lycopodites Stockii Kidston.

In some cases the fructification is in the form of terminal cones. The sporangium is placed at the base of the bract, and in form and position, as far as one can observe from impressions, seems to agree entirely with that of Lycopodium. In the other case the sporangia are borne at the base of the leaves on an ordinary branch, which has apparently undergone little or no modification, as in Lycopodites ciliatus Kidston. Such forms compare with the common Lycopodium selago of our hills and moors.

It is not yet known whether Lycopodites produced only one kind of spore (isosporous) or two kinds, macrospores and microspores (heterosporous).

Another genus which is placed in this group is Archceosigillaria Kidston, represented by a single species, Archcesigillaria vanuxemi Göpp., sp. It is very rare, and the only examples I have seen are from the Lower Carboniferous of Westmorland.

\section{II.-LEPIDODENDREA.}

Lepidodendron Sternberg. This is one of the most common genera of Carboniferous plants, and occurs plentifully throughout the whole formation.

The Lepidodendra were of arborescent dimensions, attaining a height of a hundred feet, with trunks two feet and over in diameter. The stem divided dichotomously and formed a much ramified head (Plate LVI., fig. 1). The outer surface of the bark bears contiguous (Lepidodendron aculeatum Sternberg, Plate LI., fig. 1), or more or less distant (Lepidodendron serpentigerum König sp., Plate LI., fig. 2) rhomboidal or fusiform leaf-cushions, on whose surface, generally above the centre, is situated the leaf-scar. Within the leaf-scar are three punctiform cicatricules, the central being the vascular scar; 
the two lateral, which are probably glandular organs, are called the parichnos. The leaves are lanceolate, short, or long and grass-like, with a single nerve.

The leaf-cushions were probably considerably elevated in the living plant, as impressions frequently show them in this state. The

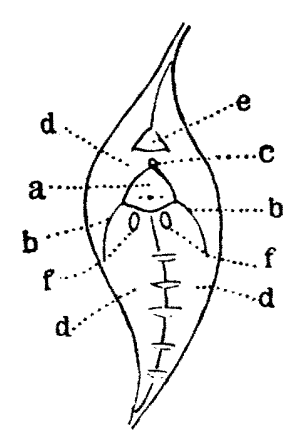

Fig. 1,-Leaf eushion of Lepidodendron aculeatum Sternb., slightly enlarged. For deseription see text.

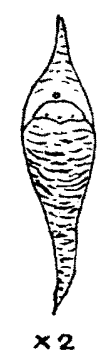

Fig. 2.-Lepidodendron Wortheni Lx. Leaf cushion, showing ornamentation. (No. 2731.) flattened condition in which they are usually found is in all likelihood the result of pressure and the collapse through decay of the more delicate inner tissue. When the leaf-cushions are distant, the cortex between them is in variably ornamented with fine, irregular, longitudinal, flexuous lines, as seen on Lepidodendron serpentigerum König. (Plate LI., fig. 2). The sub-cortical surface is generally longitudinally striated, and the single cicatrice here shown is the scar of the vascular bundle.

The following terms have been applied to the various parts of the leaf-cushion and scar. Within the cushion is the leaf-scar, Text Fig. 1, $a$, in form generally rhomboidal or sub-triangular, and containing the vascular scar and the two parichnos; extending both above and below the leaf-scar is a central keel which often bears notches on its lower part. Immediately above the leaf-scar, in the line of the central keel, is a small cicatricule called the ligule scar, $c$, and just beyond it is generally the small triangular notch, $e$. The area surrounding the leafscar is the "field," $d$. In most species of Lepidodendra immediately below the leaf-scar are two oval pits, one on each side of the keel; these are probably glandular organs, $f$. The "field" is generally free from any markings, but in Lepidodendron Wortheni Lesqx. 
KIDSTON : THE FLORA OF THE CARBONIFEROUS PERIOD.

Plate LI., fig. 3 and text fig. 2) and Lepidodendron acuminatum Göp. sp., it is ornamented with irregular transverse lines.

The fructification consists of cones (Lepidostrobus), and in the great majority of species these terminate the small branches (Plate LII., fig. 2). In a few species, as in Lepidodendron Veltheimianum Sternb. (Plate LVII., fig. 1), the cones are sessile and are borne on the large stems in two opposite rows, the cones of one row alternating with those of the other row. It is a peculiar and marked character of these so-called Ulodendroid Lycopods that the fructification is only produced on stems of considerable size and age. When the cones at maturity fall from the stem they leave a small cup-like depression, which, during the subsequent life of the tree, increases in size as the tree increases in girth.

In many species the cones contain macrospores in the lower sporangia and microspores in the upper sporangia, but whether all the Lepidodendra possessed heterosporus cones or not, is not yet ascertained.

If a well-developed stem of Lepidodendron showing structure is examined, it will be found in most cases to consist of a central pith, surrounded by a zone of primary wood, the component elements of which are arranged without definite order, and to which when once formed no inerease takes place. This is succeeded by a zone of secondary wood with medullary rays, in which the elements are arranged in radial order. Immediately outside is a cambium from which additions are made to the secondary wood, by which means its extent of increase in width is only limited by the life of the tree. The whole is surrounded by a very thick cortex, generally separable into three zones, which have been termed the inner, middle, and outer cortex. The outer cortex consists of long, tough, fibrous tissue, which adds strength and hardness to the outer portion of the bark. The leaf-bundles spring from the outer surface of the primary wood and passing upwards and outwards enter the leaves.

Some species have a solid axis and are destitute of a pith, while in a few supposed Lepidodendron stems secondary wood has not yet been observed, but this may simply be that sufficiently old stems for the development of secondary wood in these species have not yet been discovered. 
348 KIDSTON : THE FLORA OF THE CARBONIFEROUS PERIOD.

Lepidophloios Sternberg. Plants of arborescent growth with dichotomous ramification (Lepidophloios Scoticus Kidston, Plate LV., fig. 1). Stem and branches bearing well-developed scale-like leaf-cushions, at or near whose summit is placed the leaf-scar. Leafcushions imbricated, pedicel-like (Plate IV., fig. 2), upright or deflexed, exposed portion with slightly curved or straight sides, or rhomboidal in outline (Lepidophloios laricinus Sternbg., Plate LVI., fig. 2), smooth or keeled, sometimes provided with a small tubercle immediately beneath the leaf-scar. Leaf-scars rhomboidal or

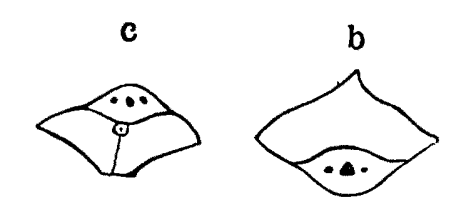

a

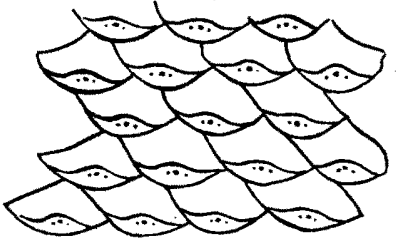

Fig. 3.- $a$, Lepidophloios Scoticus Kidston, natural size; $b$, cushion and leaf-scar, enlarged (No. 529); $c$, Lepidophloios acerosus $\mathrm{L}$. and H. sp., cushion and leaf-scar, enlarged. (No. 768.) rhomboidal elongate, with lateral angles rounded or acute. Within the leaf-scar are three punctiform cicatricules, of which the central is the vascular scar. Subcortical cicatrice single.

The fructification is borne on specialised branches, and consists of caducous stalked cones arranged in several spirals (Plate LV., fig. 3).

Lepidophloios is not nearly so common as Lepidodendron, and is easily distinguished from that genus by the form of the cushion and the position of the leaf-scar, which is always at the upper end of the pedicel-like cushion, though when the cushion becomes deflexed the leaf-scar appears as if placed at the base, Text Fig. 3. The exposed portion of cushion and leaf-scar combined is generally of rhomboidal form (Plate LVI., fig. 2).

The mode of fructification is also very different from that of Lepidodendron. The cones (Lepidostrobus) are always developed in several spiral series; they are stalked, but the stalks as well as the cones are deciduous, and on falling leave a circle of deflexed leafcushions with a small central point (Plate LV., figs. 1 and 2).

Decorticated examples of fruiting branches of Lepidophloios 
were named Halonia (Plate LIII., fig. 2) before their true nature was known. In this condition the stem bears spirally-placed rows of mamillæ-like protuberances, but in the corticated condition the depressions between the mamillæ were filled up with the cortex, so that when the bark is present they rise little above the general level of the branch (Plate LV., fig. 2).

The structure of the stem is similar in type to that of Lepidodendron, though the secondary wood appears to be produced at a later period and in some species it has not yet been observed.

Lepidophloios occurs in both the Upper and Lower Carboniferous.

Lepidostrobus Brongniart. In Lepidostrobus are placed the cylindrical, ovoid, or oblong cones with a ligneous axis and singlenerved bracts or sporophylls arranged in spirals (Plate LII., fig. 2, and Plate LV., fig. 3). The bracts consist of two parts, a basal portion or pedicel springing from the axis almost at right angles, and on which is placed the sporangium, and a limb which extends upwards at an acute angle from the extremity of the pedicel, Text Fig. 4. The

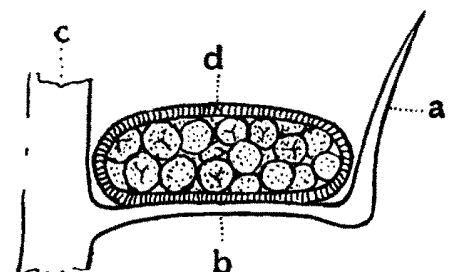

Fig. 4.-Lepidostrobus-c, axis ; $b$, bract or sporophyll, bearing sporangium $d$, containing macrospores; $\alpha$, limb of bract. (Restored.)

lower bracts bear the macrosporangia, and the upper the microsporangia. The macrospores are smooth or apiculate and are provided with a triradiate ridge.

Lepidostrobi are extremely common in Carboniferous strata, but in the majority of cases it is impossible to refer them to the parent plant, hence they are placed in the provisional genus Lepidostrobus, in which are included cones belonging to Lepidodendron, Lepidophloios, and Bothrodendron.

Lepidophyllum Brongniart. Lepidophyllum embraces the singlenerved, more or less lanceolate leaves so frequently met with, and which it is impossible to refer to the plants which have borne them, Text Fig. 5. They belong in part to Lepidodendron and Lepidophloios, and also to some Sigillaria. 


\section{III.-BOTHRODENDREF.}

Bothrodendron Lindley and Hutton. The Bothrodendra form one of the most interesting genera of the arborescent Lycopods.

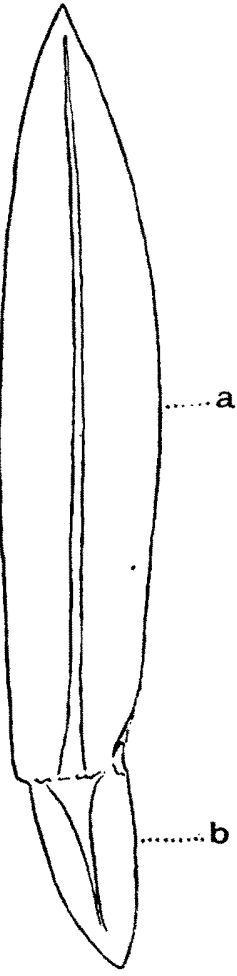

Fig. 5. - LepidophylIum (Lepidostrobus?) majus Brongt. (No. 2527.) Natural size.

Their stems ramified by dichotomous division (Bothrodendron minutifolium Boulay sp., Plate LIV., fig. 1). On the mature stem the small distant leaf-scars, surmounted with a small cicatricule, are oval or oval with more or less prominent lateral angles, and contain three punctiform cicatricules. The bark between the cushionless leaf-scars is ornamented in all eases with perhaps one exception. In the common Lower and Middle Coal Measure species, Bothrodendron minutifolium Boulay sp., it is beautifully adorned with a series of short, transverse, irregular lines and corrugations, which divide the outer surface into very numerous small, irregular, vermicular, oblong shagreen, each particle of which bears a row of little pit-like dots, Text Fig. 6. This beautiful structure can only be seen with a lens, the leaf-scars themselves being only about onetwentieth of an inch in diameter.

On the young branches of Bothrodendron minutifolium, and possibly on other species also, we find a most interesting con-
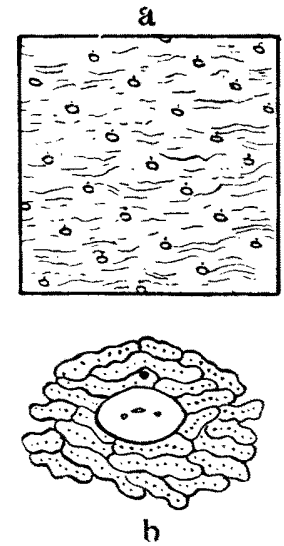

Fig. 6.--Bothrortendron mimutifolium Boulay sp. $a$, Portion of stem, natural size; $b$, leafscar and ornamentabtion of bark, enlarged. dition of the leaf-scar The young branches bear finely-corrugated, 
elongated, rhomboidal cushions (Plate LIV., fig. 2), near whose centre is placed the small leaf-scar. As growth proceeds, and at an early period, these cushions become entirely effaced, and the leafscars are carried more widely apart (Plate LIV., fig. 1 at $a$, and fig. 3). Small twigs showing the cushions might easily be mistaken for young branchlets of Lepidodendron.

Of two species the mode of fructification is known. In Bothrodendron minutifolium it consists of long slender cones (Plate LIX., fig. 2), with bracts arranged either in close whorls or very gentle spirals, but which I cannot at present determine. These slender cones terminate small branchlets. In the other species, Bothrodendron punctatum L. and $\mathrm{H}$., the fructification consists of sessile cones borne in two vertical rows which gave rise to cup-like depressions on the stem in a similar manner to that pointed out when speaking of the fructification of the Ulodendroid section of Lepidodendron. These fruiting portions of Bothrodendron can, however, even when decorticated, be easily distinguished from the corresponding state of Lepidodendron by the position of the umbilicus of the cone scar. In Lepidodendron it is always central, in Bothrodendron it is eccentric and always placed near the

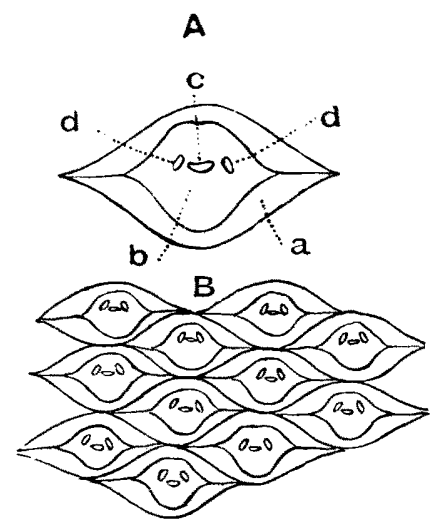

Fig. 7.-Sigillaria Brardii Brongt. Cope's Marl Pit, Longton, Staffordshire. Shale above Peacock coal, Middle Coal Measures. A, Leaf cushion $(a)$. Leaf scar $(b)$; $c$, cicatricule of vascular bundle; $d d$, parichnos; enlarged. (No 817.) lower margin of the cup-like depression.

The leaves of Bothrodendron minutifolium and Bothrodendron punctatum, the only two Carboniferous species of which the foliage is known, are small, single-nerved, and broadly lanceolate.

The internal structure of the stem is unknown.

The genus is represented both in the Upper and Lower Carboniferous, but is very rare in the latter division. 
The Bothrodendra, in the characters they possess, seem to hold an intermediate position between the Lepidodendra and the Sigillarice.

$$
\text { IV.-SIGIILARIEA. }
$$

Sigillaria Brongniart. Arborescent Lycopods, with cactuslike or columnar trunks, or very sparingly dichotomously branched stems. The bark is longitudinally ribbed or smooth. The hexagonal leaf-scars are contiguous, Text Fig. 7, or distant with more or less
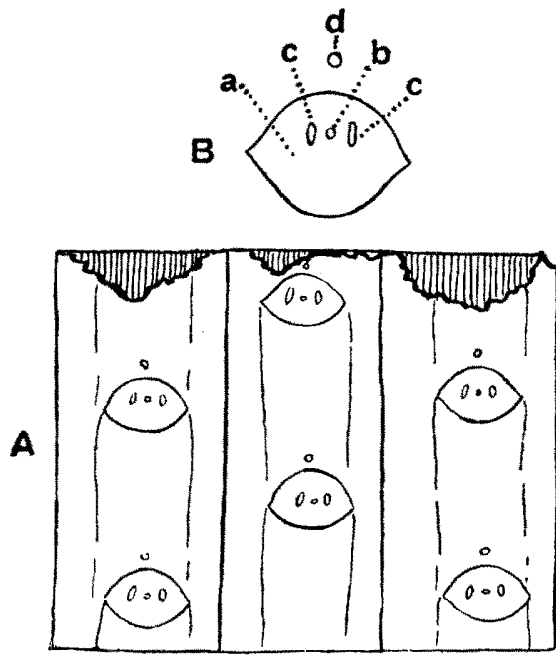

Fig. 8.-Sigillaria principis Weiss. Old Mills Pit, Farrington-Gurney, Somerset. Hor. Lower Series of the Upper Coal Measures. A, natural size; $B$, leaf-scar enlarged; $a$, area of scar ; $b$, cicatrice of vasoular bundle; $c c$, parichnos; $d$, "ligule" scar. (No. 421.) rounded angles, the two lateral angles being most prominently developed, Text Fig. 8. Within the leafscar are three cicatricules, of which the central is punctiform, transversely elongate, or sub-triangular; the two lateral are upright, and either straight or lunate, and larger than the central vascular scar. The leaf-scar is frequently placed on a more or less prominent elevation, which in the case of the ribbed Sigillarice slopes downwards from the leaf-sear. Immediately above the leafscar a small cicatricule is frequently present. Subepidermal cicatrices, three; the two lateral vertical, large and lunate, or straight, and united in the centre by the circular or oblong vascular scar; or two through the obliteration of the central scar. They attain considerable size on old stems and, through coalescence, sometimes appear as one large scar. The sub-epidermal surface is longitudinally striated.

The leaves are single-nerved, linear lanceolate, or long and grass-like. 
The fructification is in the form of caducous cones (Sigillariostrobus), in some stalked (Plate LV., fig. 4) and placed in the hollows between the ribs (Sigillaria mamillaris Brongt., Plate LXI., fig. 3), or between the leaves (Sigillaria Brardii Brongt., Plate LVIII., fig. 3 at $a$ ) in the non-ribbed species. On falling from the stem the stalk leaves a distinet circular, or irregular, shaped sear. The cones form regular verticils of a single row (Sigillaria elegans Sternb. sp., Plate LVIII., fig. 3), or of several rows (Sigillaria tessellata var. nodosa Bowman sp., Plate LVIII., fig. 1), or may be somewhat irregularly placed, especially on the non-ribbed species. In others the cones are sessile and form two opposite alternate rows (Plate LII., fig. 4), leaving, when shed, two vertical rows of cup-like depressions with a central umbilicus (Sigillaria discophora König. sp., Plate LX., fig. 1). (Ulodendron L. and H. in part.)

The Rhizome of most species of Sigillarice is Stigmaria Brongt., in others Stigmariopsis Grand 'Eury.

The Sigillarice have been divided into four sections, according to whether the stem is ribbed or smooth, and whether the leaves are close or more or less distant. These four groups, though well characterised in some species, pass into each other, and though they may assist in classifying a very difficult genus, they cannot be regarded as natural divisions or genera as originally supposed. In all, the leaf-scar is of similar structure.

SEction I.-Rhytidolepis Sternberg.

In this section the stems are distinctly ribbed, the ribs straight or slightly flexuous, with surface smooth or variously ornamented. Leaf-scars alternate on neighbouring ribs and occupying the whole or only part of the width of the rib, either close or more or less distant. There is frequently a transverse lunate depression above the leaf-scar. The cone scars are situated in the furrows. Typical form, Sigillaria mamillaris Brongt. (Plate LXI., fig. 3).

Section II.-Favularia Sternberg.

Stem ribbed, ribs flexuous and divided into sub-hexagonal compartments by transverse depressions. Leaf-scars alternate, occupying the whole width of the rib and resting on each other, or 
only separated by a very narrow space. The lateral angles of the alternate leaf-scars project slightly and impart to the furrows a more or less zig-zag course (Sigillaria elegans Sternb. sp., Plate LVIII., fig. 3). The cone scars form a verticel round the stem.

The ehief distinguishing character of this section is the close leafscars and zig-zag furrows.

SECTION III-Clathraria Brongniart.

Stems without ribs with leaves placed on contiguous, slightly elevated, rhomboidal cushions, which are separated by deep oblique furrows. Cone scars forming irregular verticils and placed in the furrows between the leaf-cushions, or in two opposite vertical rows.

Typical form, Sigillaria Brardii Brongt. (Plate LVIII., fig. 2).

Section IV.-Leiodermaria Goldenberg.

Stems without ribs having distant leaf-scars without cushions. Surface of bark between the leaf-scars variously ornamented, often with fine longitudinal, flexuous striæ, which are frequently crosshatched with delicate lines (Sigillaria camptotcenia Wood sp., Plate I.XI., fig. 2). The cone scars form irregular broad verticils.

The Rhytidolepis and Favularia sections pass into each other, and only in a very few species can the distinction be observed.

Any interfoliar space on the surface of the ribs is seldom or never entirely free from some ornamentation in the form of transverse lines or small irregular punctations, especially immediately above and below the leaf-scar. Sometimes these ornamentations are very prominent and form a distinct central band connecting the leaf-scars (Sigillaria rugosa Brongt., Plate LXI., fig. 1). A slightly raised line generally descends from the lateral angles, occasionally extending to the lower leaf-scar and forming the limit of the central band of ornamentation.

The two sections Clathraria and Leiodermaria also pass into each other ; in fact, they occur on the same specimen (Plate LIX., fig. 1), and thus appear to be only conditions of growth. The distance or approximation of the leaf-scar cannot always be regarded as a specific mark, for even in the ribbed Sigillariæ, with normally distant leafscars, specimens are occasionally found on which, apparently from 
enfeebled conditions, the leaf-scars become approximated (Sigillaria Sauveuri Zeiller, Plate LIV., fig. 4). There are, therefore, really only two sections, those with ribs and those with smooth or unribbed stems.

Those species with the cones arranged in two vertical rows are few in number. Sigillaria discophora König sp. (=Ulodendron minus L. and H.) (Plate LX., fig. 1) is frequent in the Upper Carboniferous, while another Ulodendroid form, Sigillaria Taylori Carr sp., occurs in the Lower Carboniferous.

The leaves in the great majority of Sigillarice are long and grass-like, with a single nerve, but a few had shorter lanceolate leaves.

The cones of Sigillaria (Sigitlariostrobus) have hitherto always been diseovered separated from their parent trunks though frequently attached to their pedicels, and from one such showing the Sigillarian leaf-sear, M. Zeiller was able to prove their Sigillarian origin. The Sigillarian origin of these cones had long been suspected, but satisfactory proof was wanting.

Owing to our inability of associating these cones with the species to which they belong they are placed in the genus Sigillariostrobus (Plate LV., fig. 4). These cones differ essentially in their strueture from those of Lepidostrobus. In Lepidostrobus the

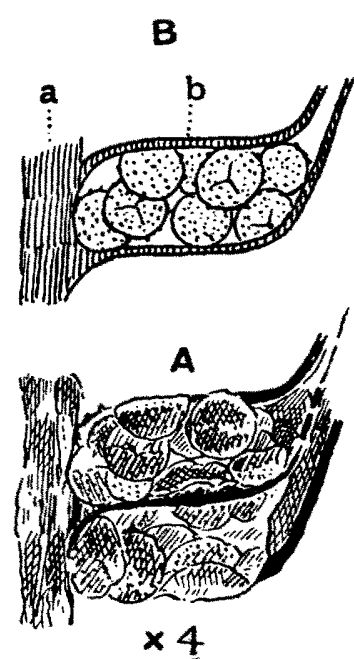

Fig. 9,-Sigilliariostrobus ciliatus Kidston. A, two sporangia containing macrospores $(\times 4)$. B, restoration of sporangium- $a$, axis ; $b$, wall of sporangium. sporangia are placed on the pedicel-

like portion of the bract, whereas in Sigillariostrobus the sporangia are developed within the inflated and hollowed-out substance of the base of the bract, Text Fig. 9. The cones of Sigillaria were probably heterosporous; at least one specimen I possess points to this conclusion, but owing to the imperfection of this example, the opinion requires confirmation before being definitely adopted. 
The structure of the Sigillarian stem is. in some cases, of the same type as occurs in Lepidodendron where the primary wood forms a close ring enclosing the pith; in other examples the primary wood forms a circle of distinct, but closely-placed, vascular wedges. These two types pass into each other, the passage taking place even in the same specimen, by the lateral union of the wedges among themselves. As in Lepidodendron, increase to the vascular system takes place by the addition of a zone of secondary wood from a cambium layer. The whole is enclosed by a thick bark.

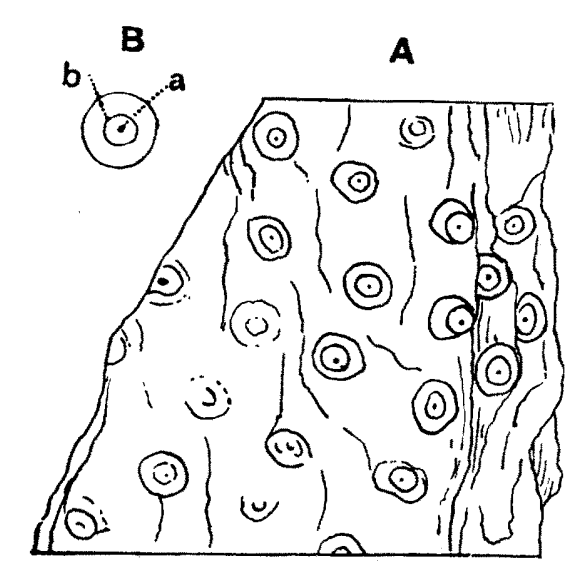

Fig. 10.-Stigmaria ficoides Sterub. sp.

A, portion of rhizome, natural size;

$B$, rootlet scar-a, vascular cicatrice; $b$, circular depression.
Sigillaria is an extremely distinct genus which comprises many species. It is rare in Lower Carboniferous times, and reaches its maximum development in the Middle Coal Measures, where it is represented by a considerable number of species.

The Sigillarice must also have played a most important part in the formation of coal, and probably the spore-bands, to which reference has already been made, were largely contri-

buted to by spores from Sigillarian cones.

Stigmaria Brongniart. Stigmaria (Plate LVI., fig. 3, and Text fig. 10), which is the rhizome of the arborescent Lycopods, diverges from the base of the trunk in four main branches. Shortly after leaving the trunk these again bifurcate, forming eight branches, and again, at a distance of a few feet from the previous fork, these bifurcate into sixteen branches. They do not again divide, or if so, only very rarely. Any terminations I have seen end in a blunt point.

The outer surface of the cortex bears quincuncially-arranged rootlet scars, consisting of a slightly raised rim, containing a circular 
depressed ring placed about midway between the central single vascular eicatrice and the outer margin of the scar, Text Fig. 10. The rootlets are very long and bifurcate at the extremity, though it is seldom that one finds them in this perfect condition. It is possible that some of the rootlets did not bifurcate, but remained simple.

Specimens of Stigmaria showing structure are not uncommon. The rhizome consists of a large pith surrounded by a zone of exogenously developed scalariform tracheides, which is divided into a number of wedges by the thick primary medullary rays. These wedges again contain many less prominent secondary medullary rays. The vascular system is enclosed in a thick cortex. The cast of the pith cavity shows the impression of the netted cylinder of the vascular axis (Plate LII., fig. 3), which is a distinguishing character between Stigmaria and Stigmariopsis.

Stigmaria is the most common fossil one meets with in Carboniferous rocks. It is the rhizome of Lepidodendron, many Sigillarioe, and most probably also of Lepidophloios, though it has not been actually found united to the stems of the last-mentioned genus.

Several species and varieties occur, the characters being founded on the size of the rootlet scars and the ornamentation of the outer surface of the bark.

Stigmariopsis Grand 'Eury. Though this genus is closely related to Stigmaria, from the investigations of Solms-Laubach, it must, I think, be separated from it. It is true that little is known of the organisation of Stigmariopsis, but the little known appears sufficient to raise the fossil to generic rank.

Stigmariopsis (Stigmariopsis anglica Kidston, Plate LI., fig. 4) is founded on Stigmaria-like rhizomes which are proportionately shorter and thicker. They spring from the hollow cup-like base of a Sigillarian stem in four primary arms, which again bifurcate, possibly several times. From the lower surface of the four primary divisions, immediately at the base of the trunk, spring downward directed conical growth-the tap-roots of R. Brown. The surface of the rhizomes and tap-root-like growths bear quincuncially-arranged rootlet scars, similar in structure to those of Stigmaria. Like Stig- 
maria, the rootlets bifurcated at the extremity though some may have been simple.

The outer surface of the bark between the rootlet-scars bears an irregular reticulation of slightly raised ridges. This is probably produced by a sub-epidermal layer of sclerenchymatous tissue, the strands of which uniting amongst themselves form a net-like reticulation (Plate LI., fig. 5). The dense nature of this tissue would assert
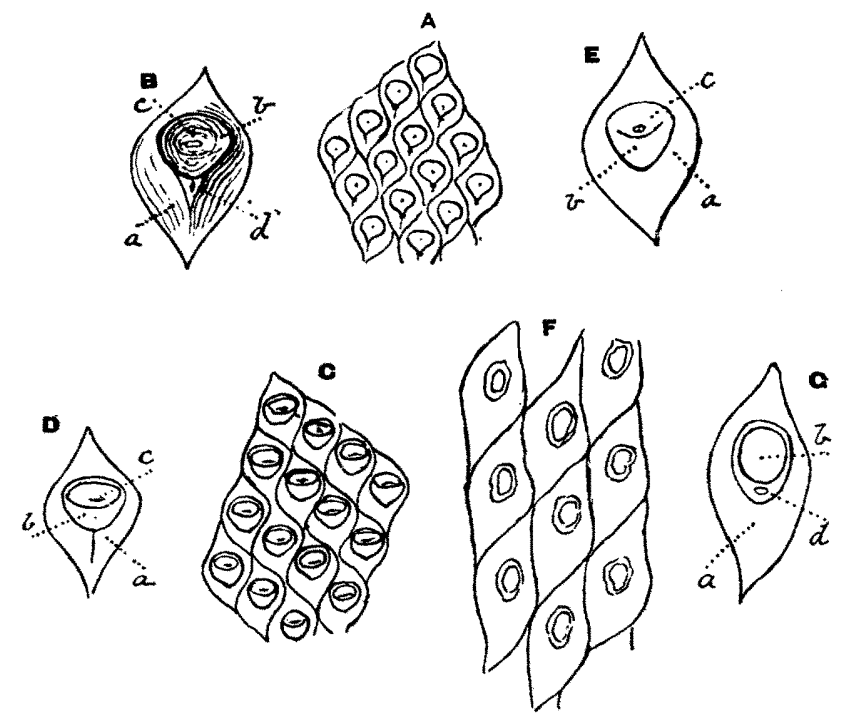

Fig. 11.-Omphalophloios anglicus Sternb. sp. A to E, from different portions of the same specimen (No. 426); $\mathrm{F}$ and $\mathrm{G}$, portions of another example (No. 433) ; A, C, and F, natural size; B, D, E, G, enlargedall from Camerton, Somerset. For explanation of lettering see text.

itself on the outer surface when the specimen was subjected to pressure and decay. The cast of the pith cavity is ribbed and somewhat in appearance like the cast of a Calamite, but without joints (Plate LIV., fig. 5).

The genus is rare in Britain, but probably more common than suspected, as it may have been passed over for Stigmaria.

The most important characters on which this genus stands are the Calamite-like ribbed east of the pith cavity, and the irregular 
mesh-like markings on the outer surface of the bark. The corresponding cast of the pith cavity of Stigmaria would, on the other hand, show the impression of the surrounding netted cylinder, the openings in the mesh being the channels through which the primary medullary rays passed out. The character of the pith east can, however, be seldom observed, and in its absence one has only the reticulated or wavy ornamentation of the outer surface of the cortex to direct one, but this seems to be a characteristic feature of the genus.

Omphalophloios White. The fossil now placed in Omphalophloios was originally described by Sternberg as Lepidodendron anglicum, and subsequently placed in Stigmaria by Brongniart.

In Omphalophloios (Omphalophloios anglicus Sternb. sp., Plate LXIV., fig. 4) the cortex is divided into clearly-defined rhomboidal areas, Text Fig. 11, A.C.F., within which, and a short distance above the centre, is an elevated sub-cordate, or oval cushion, with a slightly raised, ring-like margin, Text Fig. 11, B $b$, containing a little above its centre an oval scar with a single vascular cicatrice, Text Fig. 11, B c. Immediately below this upraised cushion, and attached as it were to its outer side, is a triangular ridge-like elevation containing a small pit, Text Fig. 11, B $d$.

Omphalophloios is probably the rhizome of one of the arborescent Lycopods, and is easily distinguished from Stigmaria on the one hand, and from Lepidodendron on the other, by the form of the vascular scar and cushion. This fossil is very rare in Britain, and has hitherto only been found in the Radstock series of the Upper Coal Measures of Somerset.

Affinities of the Carboniferous Lycopods. I can here only summarise the conclusions arrived at as to the affinities of the various Carboniferous genera of Lycopods. To give all the evidence on which these opinions are based would too far extend the present paper.

The genus Lycopodites is very closely related to the existing genera Lycopodium and Selaginella, and is probably their progenitor. Some botanists have even placed the members of the genus Lycopodites in Lycopodium, but we are scarcely warranted to take this course until we possess more definite knowledge of their fructification. 
Lepidodendron, Lepidophloios, and Bothrodendron, though they possess the essential characters of the Lycopodiacece, appear to have entirely passed away without leaving any descendants.

Sigillaria, in the manner in which the sporangia are immersed in the sporophylls, shows considerable affinity with the existing and diminutive Isoëtes. In fact, Goldenberg, many years ago, stated his belief that Sigillaria was an arborescent form of Isoëtes, and subsequent investigations have added much to strengthen this view.

\section{SPHENOPHYLLACEE.}

Sphenophyllum Brongniart. The genus Sphenophyllum holds a unique place amongst both fossil and recent plants.

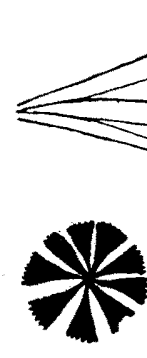

A

The various species of Sphenophyllum have slender ribbed stems with tumid or swollen nodes; the ribs do not alternate at the nodes, but continue in the same line. The internodes vary considerably in length (Sphenophyllum myriophyllum Crépin, Plate LXIII., fig. 2), and the branches are given off at irregular intervals, one branch only being given off from a node.

The leaves in the typical form are

Fig. 12.-A and B, Sphenophyllum cunefolium Sternb. sp. A, Whorl of leaves, natural size (No. 2706). B Leaf, enlarged to show teeth and nervation (No. 1566). C, Sphenophyllum trichomatosum Stur, natural size (No. 1046). cuneate, Text Fig. 12, A and B, or wedge-shaped, but they vary much, not only on different species, but even on the different parts of the plant, and this variation can be observed even on the same specimen. The normal wedgeshaped leaf passes into leaves divided into two deeply-cut lobes (Sphenophyllum majus Bronn. sp., Plate LXII., $a$ at $a$ ), which again are bifid, or they may be reduced to dichotomously-divided filiform segments which radiate fan-like from the base, Text Fig. 12, C, or may even be simple, narrow, lanceolate leaves forming a whorl round the stem. These latter seem to be restricted to the larger branches. The nervation repeatedly bifurcates, a single veinlet going into each tooth or segment of the leaf. 
The fructification, often placed on short lateral branches, is commonly in the form of terminal cones composed of more or less modified leaves whose basal portions unite to form a saucer-like collar surrounding the axis. The distal portion of the bract is free and erect. In the cones the whorls of bracts alternate, but on the stems the leaves are superposed.

In Sphenophyllum majus Bronn. sp. the fruiting portion of the plant is little modified from an ordinary foliage branch, though the bracts are united into a very narrow collar which surrounds the stem, Fig. 13.

The arrangement of the sporangia in the cones of the various species varies considerably.

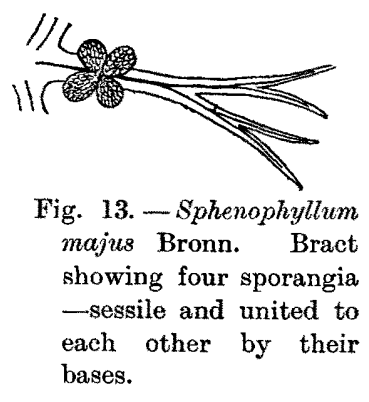

In Sphenophyllum cuneifolium, the common Middle and Lower Coal Measure species, the sporangia usually form three whorls placed on pedicels of varying length which, however, all spring from the bract close to the axis, Text Fig. 14. It therefore follows that those of the first whorl have shorter pedicels than those of the second, while those of the third whorl have pedicels

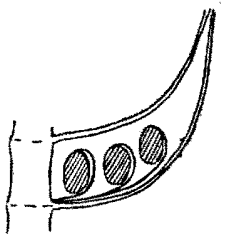

Fig. 14. - Sphenophyllum cuneifolium Sternb. sp. Arrangement of the sporangia. longer than those of the two inner circles of sporangia. A small vascular bundle enters each pedicel or sporangiophore, which is therefore most probably a modified segment of the bract.

In Sphenophyllum trichomatosum Stur the sporangia are sessile, Fig. 15. In Sphenophyllum majus Bronn. sp. the sporangia are also sessile, but united by their bases into groups of four, Fig. 13.

The spores of Sphenophyllum are very characteristic, the spore membrane being ornamented with spine-like projections connected by a series of reticulate ridges.

The stem of Sphenophyllum consists of a solid axis, formed of a primary, three-rayed, vascular star developed centripetally. To 
this is added a zone of secondary wood, formed from a cambium layer, and as this secondary zone increases in width, the star-like form of the primary wood is lost and the bundle becomes circular in form through the external addition of the secondary wood. The whole is enclosed by a firm bark.

Owing to the dimorphic condition of the leaves, it was formerly supposed by some that Sphenophyllum was an aquatic plant, but this is not the case. The whole structure of the plant makes it clear that Sphenophyllum was terrestrial, though from their long delicate stems they must have had some support to keep them in an upright position, and this support they probably found by scrambling amongst the surrounding vegetation.

Sphenophyllum, not only in the structure of its stem, but also in that of its cones, exhibits so many peculiarities that it is impossible to include it with any other group of plants. With the casts of Calamites it has a certain superficial resemblance

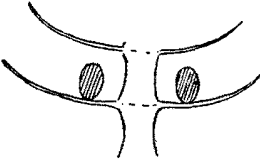

Fig. 15. - Sphenophyllum trichomatosum Stur. Arrangement of sporangia (enlarged). in its noded stems and whorled leaves, but the solid axis and non-alternating ribs of Sphenophyllum, along with its dichotomously-divided leaves as well as the structure of its cone, differ so much from the Calamites that any systematic relationship is entirely precluded. With Asterocalamites it has a greater resemblance in the ribs of both not alternating at the nodes and in the leaves being dichotomously divided, but Sphenophyllum differs here also in its solid axis and in the structure of the cone, presuming that Pothocites is the cone of Asterocalamites.

Nor with the Lycopodiaceæ does Sphenophyllum seem to have any close connection. The jointed stem, dichotomously-divided leaves, and structure of the fructification are very different from anything found amongst the Lycopods.

The genus Sphenophyllum must therefore stand alone as a peculiar and interesting type of plant which appears to have become extinct in early geological times. 


\section{GYMNOSPERMS.}

We now pass to the Gymnosperms, of which we shall briefly con sider the Cordaitece, Coniferce, Ginkgoaceo. Of the Cycadacece there is no evidence of their oceurrence in British Carboniferous rocks.

\section{Cordaiteer,}

In the Cordaitece are placed the genus Cordaites and certain genera of fossil fruits, some of which belong to Cordaites, but which, owing to our ignorance of the species of Cordaites to which they belong, necessitates their being placed in separate genera until their parentage has been ascertained. It is possible, however, that some seeds at present included in the Cordaitece may not belong to that group, but may be the seeds of other plants, which, with the exception of the fruit, may be quite unknown to us.

Cordaites Unger. This genus occupies a very prominent and important place amongst the plants of the Carboniferous Period, for though Cordaites extends into the Permian Formation it is essentially a Carboniferous genus, for the plant-bearing beds near St. John, New Brunswick, from which the late Sir William Dawson recorded Cordaites as Devonian, are, there is very strong reason to believe, really Carboniferous.

Cordaites had thick stems two feet or more in diameter, and which attained a height of 100 feet and terminated in an irregular, muchbranched, dense, leafy head.

The branches bore long, lanceolate, spathulate, or linear leaves, which in some cases must have been two feet or more in length. The leaves have parallel veins (Cordaites principalis Germar. sp., Plate LXIV., fig. 3, base of leaf, and Plate LVII., fig. 2, apex of leaf), which increase in number in the leaf by dichotomous division. In some species the veins are equally strongly marked on the surface; in others, lying between the veins are one or more finer parallel threads, which appear to represent bands of sclerenchyma rather than weaker veins.

The leaves are spirally arranged, and when shed leave a transversely oval scar on the stem (Cordaites principalis Germar. sp., Plate LIII., fig. 1). Well-preserved stems show on the leaf scars 
a transverse row of little points, the cicatrices of the numerous vascular strands which entered the leaves. The same character is observable on the bases of the shed leaves. (Plate LXIV., fig. 3.)

The leaves of Cordaites according to their form and shape are placed in the three following genera :-

Cordaites or Eucordaites. Leaves oval-lanceolate, lanceolate, or spathulate, with rounded apices (Cordaites principalis Germar. sp., Plate LVII., fig. 2).

Dorycordaites. Leaves lanceolate with sharp points (Dorycordaites palmaformis Goppert sp., Plate LVII., fig. 3).

Poacordaites. Leaves long, narrow, and grass-like. (Poacordaites microstachys Gold. sp., Plate LXIV., fig. 2.)

As a type of Cordaites, C. principalis Germar. sp. may be mentioned (Plate LVII., fig. 2., Plate LXIV., fig. 3). This is extremely common in the Middle and Lower Coal Measures.

Dorycordaites. This is represented by Dorycordaites palmoformis Göpp. sp., which, however, is rare. (Plate LVII., fig. 3.)

Poacordaites is the most rare in Britain and only occurs in the Upper Coal Measures, where Poacordaites microstachys Gold. sp. is very sparingly found. (Plate LXIV., fig. 2.)

In the Lower Carboniferous Cordaites occurs, but is extremely rare and represented by different species from those found in Upper Carboniferous rocks.

The male and female flowers are borne on different spikes, and the female organs have long been known under the name of Antholithes Pitcairnice L. and H., though their nature was not at first understood. The male flowers form a spike of distichous or spirallyarranged flowers consisting of several whorls of bracts, from among which, or perhaps springing from their centre, arise a number of filaments, bearing three or four tubular anthers.

The female infloresence generally consists of a spike of distichously grouped bracts, from the axils of which spring sessile or more or less long-stalked seeds.

These infloresences, both male and female, are now generally included under the name of Cordaianthus Grand 'Eury (Cordaianthus with Samaropsis fluitans Dawson, Plate LXV., fig. 5). 
The Structure of the Stems of Cordaites. Little was known about the structure of the stem until M. Grand 'Eury showed a few years ago that the tree described by Witham, under the name of Pinites Brandlingi, is really the stem of Cordaites. In the young state in this species the pith fills up the whole of the large medulla, but as growth proceeds, the pith not growing with the same rapidity as the surrounding tissue becomes transversely ruptured, resulting in the formation of a series of transverse lenticular cavities, forming a chambered pith. As growth continues the transverse diaphragms of pith get broken up, and eventually the pith cavity becomes an empty tube, except at its margin, to which cling annular rings of pith-the remains of the diaphragms which once extended across the cavity. Inorganic casts of these pith cavities are not uncommon, and are the fossils to which the names of Artisia or Sternbergia have been given (Artisia transversa Artis. sp., Plate LXV., fig. 6). Surrounding the pith in Cordaites (Pinites) Brandlingi is a zone of secondary wood, which consists of radially-arranged tracheides, separated by primary and secondary medullary rays, of one cell in thickness. The first-formed elements of the wood, the protoxylem, formed of narrow spiral tracheides, are followed by larger spiral tracheides; these are succeeded by scalariform tracheides, and then follow tracheides characterised by laterally-placed bordered pits with an oblique opening. It is this latter tissue which forms the bulk of the wood, to which additions are made from a cambium layer. The wood is enclosed by a thick cortex whose outer portion contains bands of dense, thick-walled fibrous tissue. The leaf-bundles which usually appear in pairs in transverse sections of the stem, before entering the leaf split up into numerous small strands, which pursue a parallel course through the leaf as already deseribed. What are probably the roots of Cordaites have been described under the name of Amyelon.

True, "annual rings" seem to be absent from Pinites or Araucarioxylon (Cordaites) stems, though specimens are occasionally met with where layers of feebly-developed wood are separated by broad bands of wood fibres of normal size.

In Cordaites (Pinites) Brandlingi it is thus seen no primary wood occurs, the whole of the tracheides consisting of secondary wood. 
KIDSTON: THE FLORA OF THE CARBONIFEROUS PERIOD.

Some other stems, however, which have been referred to Araucarioxylon (Pinites) or Dadoxylon, such as Araucarioxylon Beinertianum Göpp. sp. and Pitus (Araucarioxylon) antiqua Witham and others, in which the secondary wood agrees in all essential characters with that just described, possess primary as well as secondary wood. According to the species, the primary wood consists of few or many isolated groups of tracheides, usually of small extent, which are situated in the pith elose to the surrounding zone of secondary wood, or resting on it. To these bundles no additions of new elements are made when once they are fully developed. It is probable that these stems, with primary and secondary wood, either in whole or in part, also belong to Cordaites. Many of these have been found in the Lower Carboniferous, especially in the Calciferous Sandstone series, where, however, Cordaites leaves are rare. This may be only an accident of circumstances, for in the beds where the large trees are found, almost invariably no other plant-remains are discovered with them. In every case which has come under my observation they occur as drift trees, generally embedded in sandstone or other coarsegrained material where delicate fossils could not be preserved. Their cortex, also, with one exception, has always disappeared through decay or attrition. It must also be further borne in mind that a natural sorting takes place in all water-carried vegetable material; the smaller coming to rest at one place and the larger, such as tree trunks, at another.

Such is the manner of distribution in which we generally find fossil plants to occur.

The structure of the stems we have just been considering leads to very important conclusions in regard to the affinities of these plants. It has generally been considered, and as often stated, that these so-called Dadoxylon or Araucarioxylon stems belong to the Coniferce; in fact, it has been usual to suppose that the Coniferce occupied a very important place in older palæozoic times; this, however, is not the ease, for although in the structure of the secondary wood a great similarity is shown to that of Araucaria, still other more important structural characters, such as the large chambered pith and, when present, the mesarch structure of the primary bundles point much more to their affinity being with the Cucadacece. 
The Cordaitece, however, possess distinctive characters of their own, and though showing more affinity to the Cycads than to the Conifers, form a distinct group which cannot be united with either, but must be regarded as equal in importance with them.

SEEDS.

Many isolated gymnospermous seeds occur in the Carboniferous rocks of which some certainly belong to the Cordaites. These, according to their form and structure, have been placed in many genera, as. it is seldom ever possible to refer them satisfactorily to their parent stems. The more important of these genera are :-

Samaropsis Göppert. Generally small oval seeds, lenticular in section, pointed at the apex and rounded or slightly cordate at the base, and surrounded by a more or less prominent membranous wing with a notched or acute apex (Samaropsis bicaudata Kidston, Plate LVIII., figs. 5-6).

Cardiocarpus Brongniart. Smooth flattened seeds, oval or circular in outline, sharp or obtuse at summit, sometimes slightly cordate at the base and surrounded by a more or less distinet marginal wing (Cardiocarpus ef. emarginatus Artis. sp., Plate LXI., fig. 5).

Carpolithes Schlotheim. Smooth oval seeds, generally of small size, without any wing and not cordate at base (Carpolithes perpusillus Lesquereux, Plate LXV., fig. 4, and Carpolithes ovoideus Göppert and Berger, Plate LII., fig. 1).

Rhabdocarpus Göppert and Berger. Oval or cordate seeds containing a hard nucule surrounded by a more or less fleshy envelope in which are numerous hypodermic strands that impart a striated appearance to the outer surface of the compressed fruit (Rhabdocarpus multistriatus Sternberg sp., Plate LXI., fig. 4).

Trigonocarpus Brongniart. Hard, nut-like, oval seeds, circular in transverse section and provided with three prominent, and between them three less prominent, ridges. Before maturity the seed is surrounded by a large pericarp which extends considerably beyond the apex of the nut.

Figs. 1 and 2, Plate LXV., show specimens of Trigonocarpus Parkinsoni Brongt. enclosed in the pericarp. The Carpolithes alata. 
368 KIDSTON : THE FLORA OF THE CARBONIFEROUS PERIOD.

L. and H. is founded on such a condition of Trigonocarpus, and is quite distinct from the genus Carpolithes as defined above. Plate LXV., figs. $3 a, 3 b, 3 c$, show three specimens of Trigonocarpus removed from their pericarp, with the three prominent ridges.

CONIFER A.

From what has been stated when describing the Cordaitece it is seen that true members of the Coniferce are very rare in British Carboniferous rocks. The only example which has come under my notice is a small specimen of Walchia imbricata Schimper (Plate LXIII., fig. 1), which may possibly be only a form of Walchia piniformis Sternberg, from the Upper Coal Measures passed through when sinking the shaft of the Hamstead Colliery, Great Barr, near Birmingham.

In Walchia Sternberg are placed trees of a very Araucarian-like habit and growth. The branches are regularly pinnate, being arranged in two opposite or alternate rows. The spirally-placed leaves are more or less sickle-shaped, coriaceous, keeled, and widen towards their decurrent base. The fructification consists of small terminal cones, whose detailed structure has not yet been clearly made out. There is reason to believe, however, that Walchia holds a close affinity with the recent Araucaria.

GinkgoheEA.

The type and only existing species of the Ginkgoacece is the Maidenhair Tree of Japan and China-Ginkgo biloba L. = (Salisburia adiantifolia Smith). That Ginkgo is a very ancient plant type and extends far back in geological times has been clearly shown, but it is doubtful if the Noggerathia flabellata L. and H. from the Lower Coal Measures, Bensham Seam, Jarrow Colliery, which Saporta includes in his genus Ginkgophyllum under the name of Ginkgophyllum flabellatum, holds any real affinity with the true Ginkgoaceo. The leaves of Ginkgo are broadly cuneate, with a long slender petiole. The apex is irregular, and frequently divided into two or more cuneate lobes. The nervation spreads fan-like from the base of the leaf. The Ginkgoaceo are separated from the Conifer $\infty$ on account of their mode of fertilisation, which takes place through the agency of antherozoids. 
In Noggerathia flabellata L. and $\mathrm{H}$. the leaves or leaflets, for I think it is uncertain which term to apply to the ultimate divisions, are cuneate, with a slightly rounded irregular apex, and whose nervation radiates from the wedge-shaped base. Though larger than the leaves of Ginkgo, the leaves or leaflets of Noggerathia flabellata L. and $\mathrm{H}$. have a great general resemblance to them, and on account of this resemblance, perhaps only superficial, some authors have placed Lindley and Hutton's species in Ginkgophyllum.

Noggerathia flabellata L. and H. (=Psygmophyllum flabellatum Schimper) is very imperfectly known, and of its fructification we are in entire ignorance. The enrolment, therefore, of Noggerathia flabellata in the Ginkgoaceo appears to me to be on insufficient evidence. What its true systematic position is remains to be discovered.

\section{Conclusion.}

We have now passed in short review the principal genera of Carboniferous Plants. In the time at our disposal it has been impossible to mention many interesting but less common species. Nor has it been possible to enter into any detailed description of the internal organisation of the plants which we have considered. To enter into these points in detail is beyond the scope of the present paper, whose object is only to give a sketch of the more important plant groups of the Carboniferous Formation.

Many excellent Text Books are in existence, and to these I refer the student for a more complete treatment of the subject. ${ }^{*}$

* Schimper, Traité de Paléont. Végét., Vol. I.-III., Paris, 1869-74. Renault, Cours de Botanique Fossile, Vol. I.-IV., Paris, 1881-85. Schimper and Schenk in Zittel, Handbuch der Palceontologie, II. Abth. Paloeophytologie. München and Ieipzig, 1879-1890, Williamson; Williamson and Scott ; and Scott. Various papers "On the Organisation of the Fossil Plants of the Coal Measures." Phil. Trans., London. From 1871 to present date. Seward, Fossil Plants for Students of Botany and Geology, Vol. I., Cambridge, 1898 (Vol. II. not yet published). Scott, Studies in Fossil Botany, London, 1900. Graf zu Solms-Iaubach, Fossil Botany, being an Introduction to Palaophytology from the Standpoint of the Botanist, English Edition, Oxford, 1891. Schenk, Die Fossilen Pflanzenreste, Breslau, 1888. Potonié, Lehrbuch der Pflanzenpalaontologie mit besonderer Rücksicht auf die Bedürfnisse des Geologen, Berlin, 1899. Zeiller, Éléments de Paléobotanique Paris, 1900. Kidston, Carboniferous Lycopods and Sphenophylls, Trans. Nat. Hist. Soc., Glasgow., Vol. VI. (new series) part I., pp. 25-140, 1901. 
INDEX.

(Part I., pp. 189-229. Part II., pp. 344-399.)

\begin{tabular}{|c|c|c|c|c|c|c|c|}
\hline Alethopteris & . & .. & 195 & Linopteris & & .. & 194 \\
\hline Annularia & .. & . . . & 203 & Lycopodites .. & .. & .. & 344 \\
\hline Asterocalamites & & . 200 & 202 & Macrostachya & .. & . . & 204 \\
\hline Bothrodendron & . & . $\quad .$. & 350 & Mariopteris .. & .. & . & 195 \\
\hline Calamites $\quad$. & . & .. & 199 & Megaphyton & . & .. & \\
\hline Calamitina & . & . . 199, & 201 & Neuropteris .. & . . & . & 93 \\
\hline Calamocladus & .. & . $\quad$. & 202 & Nœggerathia & .. & .. & 369 \\
\hline Calamostachys & .. & .. & 203 & pteris & .. & .. & 96 \\
\hline Cardiocarpus & .. & .. & 367 & arpia .. & . & . & \\
\hline Carpolithes .. & .. & $\therefore$ & 367 & Omphalophloios & . & . & 59 \\
\hline Caulopteris & . & . & 196 & Palæostachya & . & .. & 203 \\
\hline Clathraria & . & .. & 354 & eris $\quad$. & .. & . & 94 \\
\hline Coniferæ $\quad .$. & . & . & 368 & Pin & .. & . & 04 \\
\hline Cordaianthus & .. & .. & 364 & Poacordaites .. & .. & .. & 364 \\
\hline Cordaites $\quad .$. & .. & . & 363 & ophyllum & & . & 369 \\
\hline Corynepteris & .. & . & 192 & arpus & .. & .. & 367 \\
\hline Dactylotheca & .. & .. & 195 & Rhytidolepis & . & . & 353 \\
\hline Dictyopteris & .. & . & 194 & Samaropsis .. & . & . & 367 \\
\hline Dorycordaites & .. & .. & 364 & ria $\quad \ldots$ & .. & . & 352 \\
\hline Equisetites .. & .. & . $\quad \ldots$ & 198 & Sigillariostrobus & . & . & 355 \\
\hline Eucalamites .. & .. & .. 199, & 201 & Sphenophyllum & . & .. & 360 \\
\hline Favularia $\quad .$. & . & . $\quad \ldots$ & 353 & Sphenopteris & .. & . & 191 \\
\hline Ginkgophyllum & . & . & 368 & Stigmaria $\quad .$. & .. & . & 356 \\
\hline Leiodermaria & . & .. & 354 & Stigmariopsis & . & . $\quad$. & 357 \\
\hline Lepidodendron & . & .. & 345 & Stylocalamites & & .. 200, & 202 \\
\hline Lepidophloios & .. & .. & 348 & Trigonocarpus & & .. $\quad .$. & 367 \\
\hline Lepidophyllum & . & .. & 349 & Urnatopteris & . & .. & 193 \\
\hline Lepidostrobus & .. & .. & 349 & Volkmannia & .. & . & 203 \\
\hline Lonchopteris & . & . $\quad$. & 196 & Walchia .. & .. & .. $\quad$. & 368 \\
\hline
\end{tabular}




\section{Explanation of Prates.}

\section{Plate LI}

Fig. 1. Lepidodendron aculeatum Sternberg. From near Stevenston, Ayrshire. Hor. Whistler Seam. Lower Coal Measures [2482].* Specimen received from Rev. D. Landsburgh, D.D. Portion of stem showing contiguous cushions and leaf-scars. Natural size.

Fig. 2. Lepidodendron serpentigerum König. Grange Colliery, Kilmarnock, Ayrshire. Hor. Stranger Coal. Lower Coal Measures [2498]. Specimen received from Mr. A. Sinclair. Portion of specimen showing distant cushions and leaf-scars, with interfoliar cortex ornamented with irregular fine ridges. Natural size.

Fig. 3. Lepidodendron Wortheni Lesquereux. Lower Writhlington Pit, Radstock, Somerset. Hor. Radstock Series. Upper Coal Measures [374]. Portion of stem showing contiguous leaf-cushions with short, fine, irregular, transverse ridges. Natural size.

Fig. 4. Stigmariopsis anglica Kidston. Monckton Main Colliery, near Barnsley, Yorkshire. Hor. Barnsley Thick Coal. Middle Coal Measures [2342]. Collected by Mr. Hemingway. Portion of rhizome showing rootlet scars and ornamentation of surface of cortex. Natural size.

Fig. 5. Stigmariopsis anglica Kidston. Monckton Main Pit, near Barnsley, Yorkshire. Hor. Barnsley Thick Coal. Middle Coal Measures [2335]. Collected by Mr. W. Hemingway. Portion of rhizome showing sub-epidermal surface with the characteristic ridges. Enlarged.

* The figures enclosed in brackets give the registration numbers of the specimens in the Author's collection. 


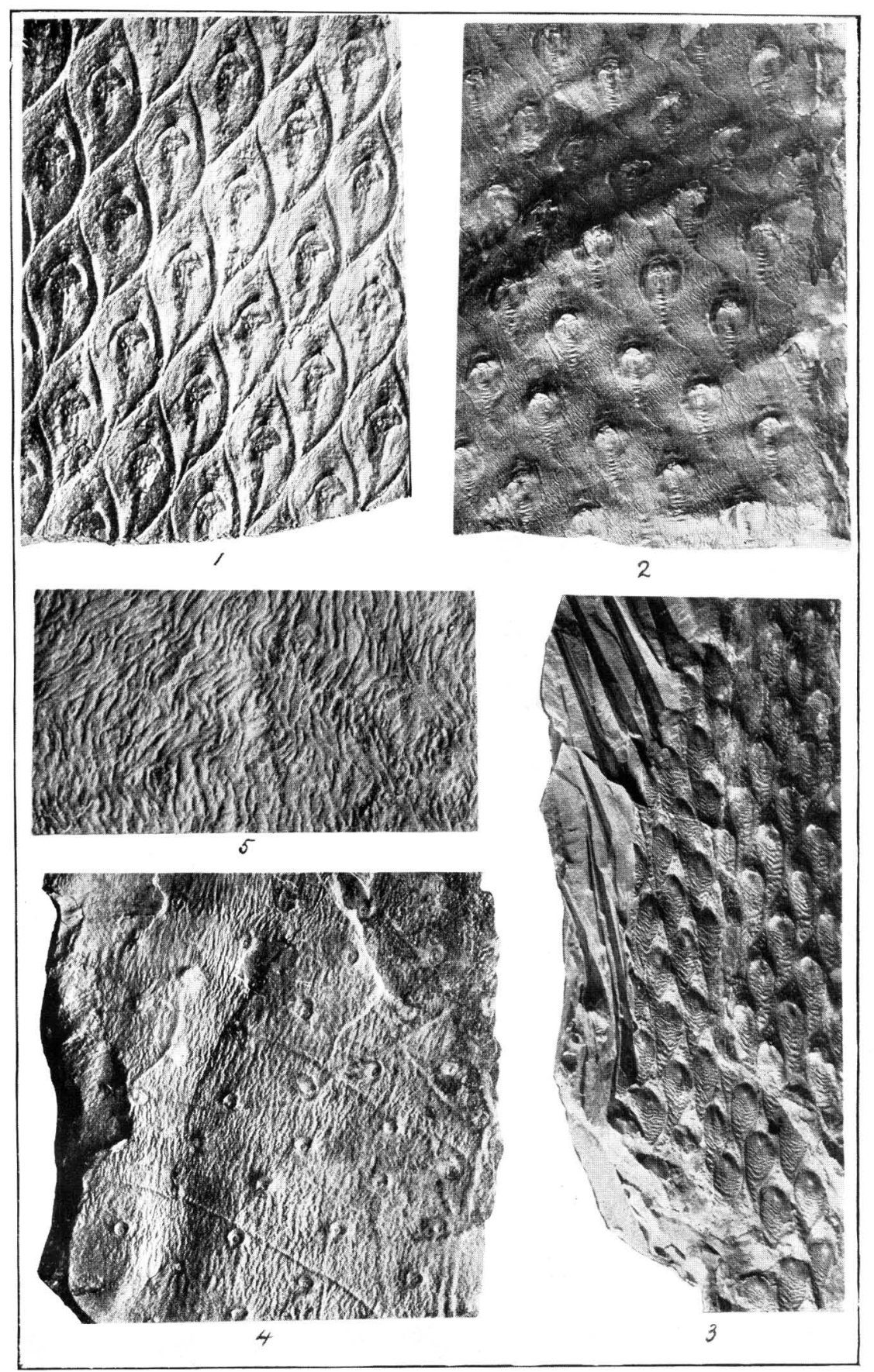

Phot ogmiphed by R. Kidsten.

Proc. Yorks. Geol. and Polytec. Soc., Vol. XIV., Plate LI. 
Plate LII.

Fig. 1. Carpolithes ovoidens Göppert an 1 Berger. Camerton, Somerset. Hor. Radstock Series. Upper Coal Measures [3021]. Collected by Mr. G. West. Portion of a slab showing a number of seeds. About natural size.

Fig. 2. Lepidodendron lycopodioides Sternberg. Monckton Main Colliery, near Barnsley, Yorkshire. Hor. Barnsley Thick Coal. Middle Coal Measures [2718]. Collected by Mr. W. Hemingway. Small branch-bearing terminal cone. About natural size.

Fig. 3. Stigmaria ficoides Sternberg sp. Calderbank, near Airdrie, Lanarkshire. Hor. Kiltongue Coal. Lower Coal Measures [2599]. Collected by Mr. R. Dunlop. At $a$ is seen the cast of the pith cavity, the raised-up fusiform ridges on which are the casts of the openings to the primary medullary rays. The wood plates are seen at $b$. About natural size.

Fig. 4. Sigillaria Taylori Carr. sp. From the bituminous Oil Shales, Midlothian. Calciferous Sindstone Series [16]. Collected by Dr. Macfarlane. Showing a vertical row of immature cones. Two-thirds natural size. 


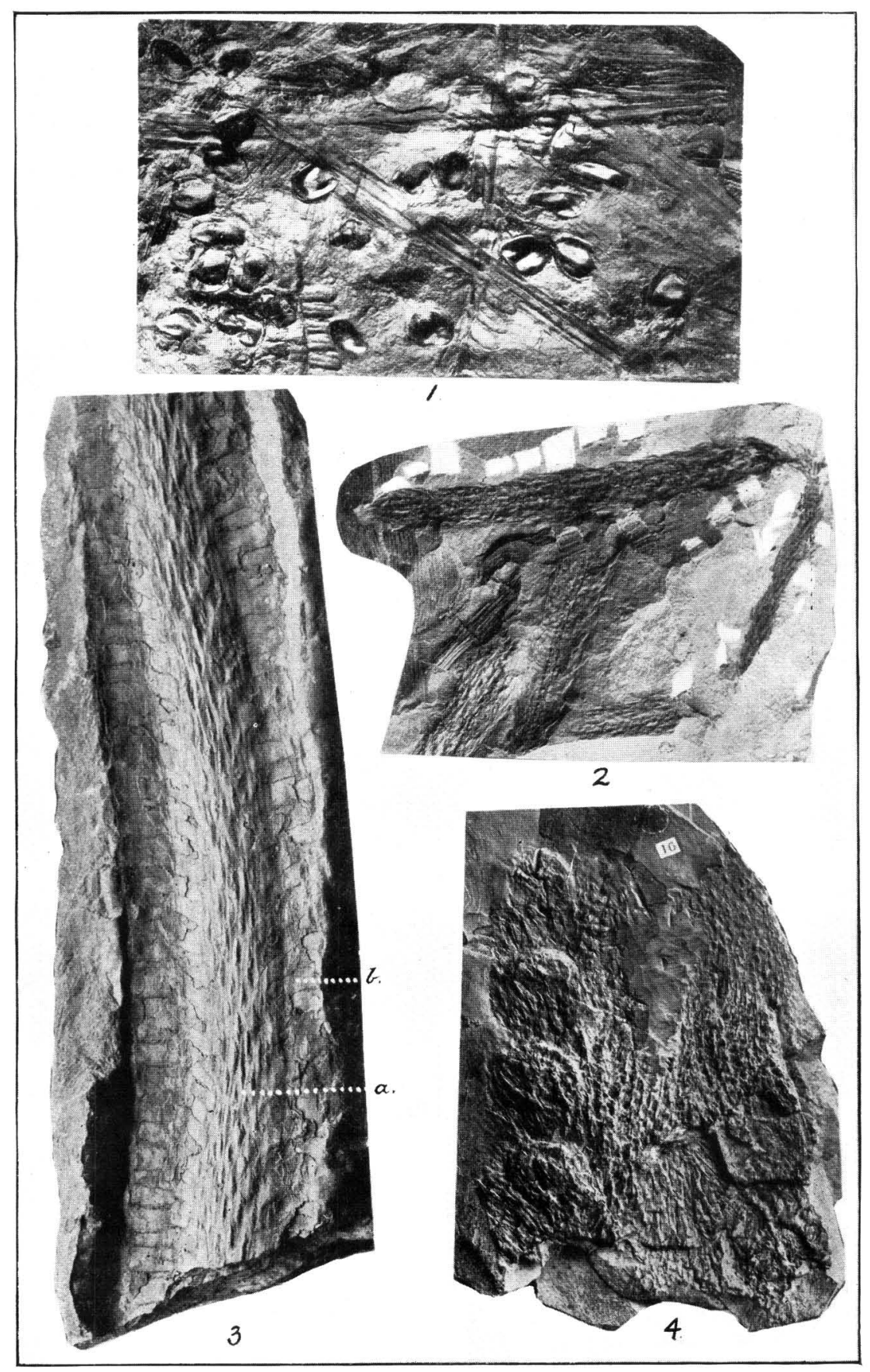

Photographed hy R. Kielston.

Proc. Yorks. Geol. and Polytec. Soc., Vol. XIV., Plate LII. 


\section{Plate LIII.}

Fig. 1. Cordaites principalis Germar. sp. Bonnington Pit, Kilmarnock, Ayrshire. Hor. Whistler Seam. Lower Coal Measures [1561]. Specimen from Rev. D. Landsburgh, D.D. Stem showing leaf-scars. About natural size.

Fig. 2. Halonia tortuosa L. and H. Smithies, near Barnsley, Yorkshire. Hor. Woolley Edge Rock. Middle Coal Measures [2176]. Collected by Mr. W. Hemingway. Decorticated fruiting branch of Lepidophloios. Twothirds natural size. 


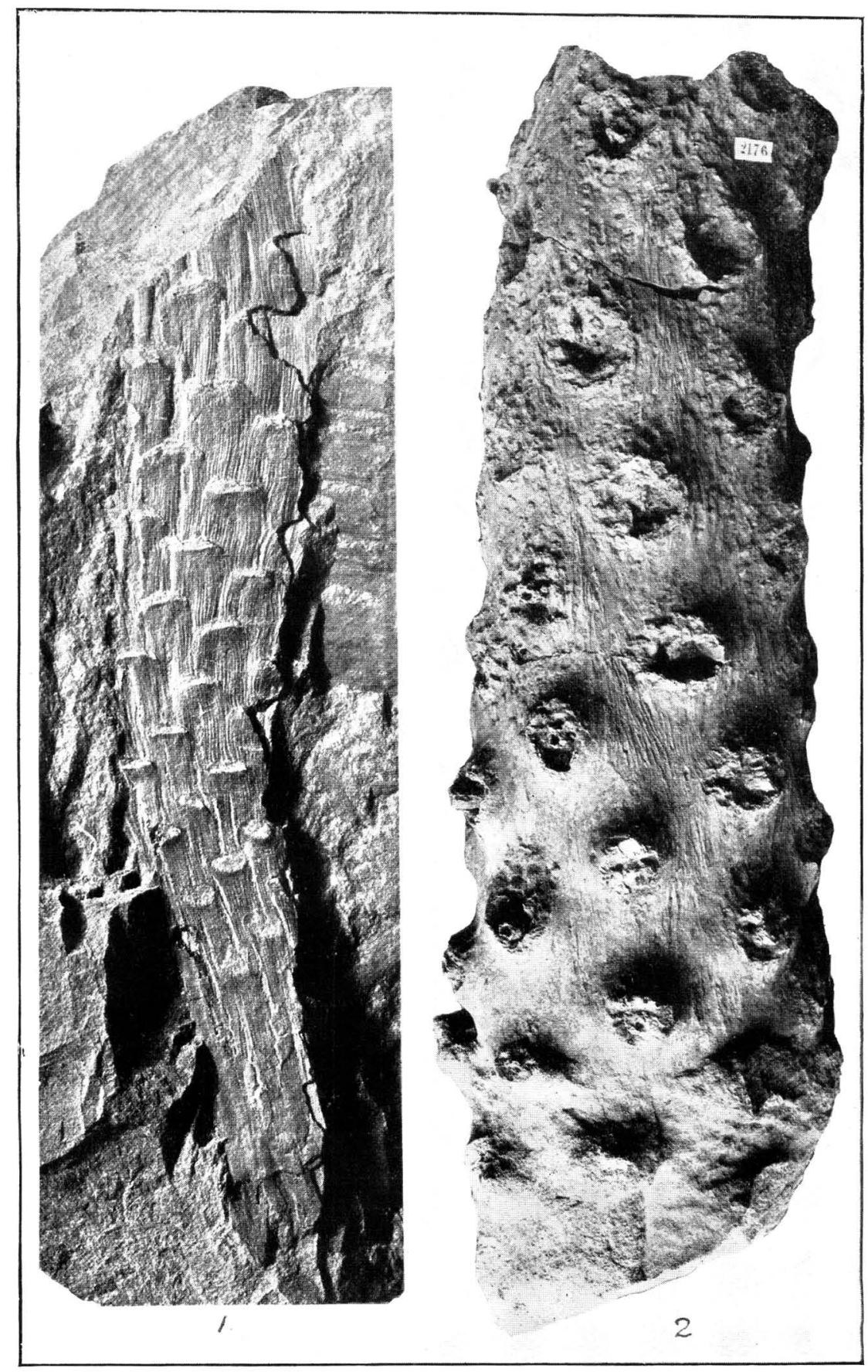

Thotegraphed by R. Kidstem.

Proc. Yorks. Geol. and Polytec. Soc., Vol. XIV., Plate IIII. 


\section{Plate LIV.}

Fig. 1. Bothrodendron minutifolium Boulay sp. Bonnington Pit, Kilmarnock, Ayrshire. Hor. Whistler Seam. Lower Coal Measures [1568]. Specimen from Rev. D. Landsburgh, D.D. At $a$ is seen the fully-developed stem with distant cushionless leaf-scars; at $b$ is shown the young condition where the stem bears rhomboidal areas in which are placed the leaf-scar; at $c$ an intermediate condition is represented. About three-quarters natural size.

Fig. 2. Bothrodendron minutifolium Boulay sp. Part marked $b$ in fig. 1 enlarged to show the rhomboidal fields or cushions bearing the leaf-scars.

Fig. 3. Bothrodendron minutifolium Boulay sp. Part marked $c$ on fig. 1 enlarged to show the still slightly elevated leafscar and the disappearance of the field.

Fig. 4. Sigillaria Sauveuri Zeiller. Longton Hall, Longton, Staffordshire. Hor. Great Row Rock. Middle Coal Measures [2199]. Collected by Mr. John Ward, F.G.S. Sigillaria of the Rhytidolepis Section, showing approximation and reduction in size of the leaf-scars, which probably represents an enfeebled condition of growth. About three-quarters natural size.

Fig. 5. Stigmariopsis. Cast of the pith eavity. Specimen communicated by Graf zu Solms-Laubach from one of the examples described in his paper "Uber Stigmariopsis Grand 'Eury." Dames u. Kayser. Palcont. Abhandl. New Series. Vol. II., part 5, page 223, 1894 [2601]. About three-quarters natural size. 


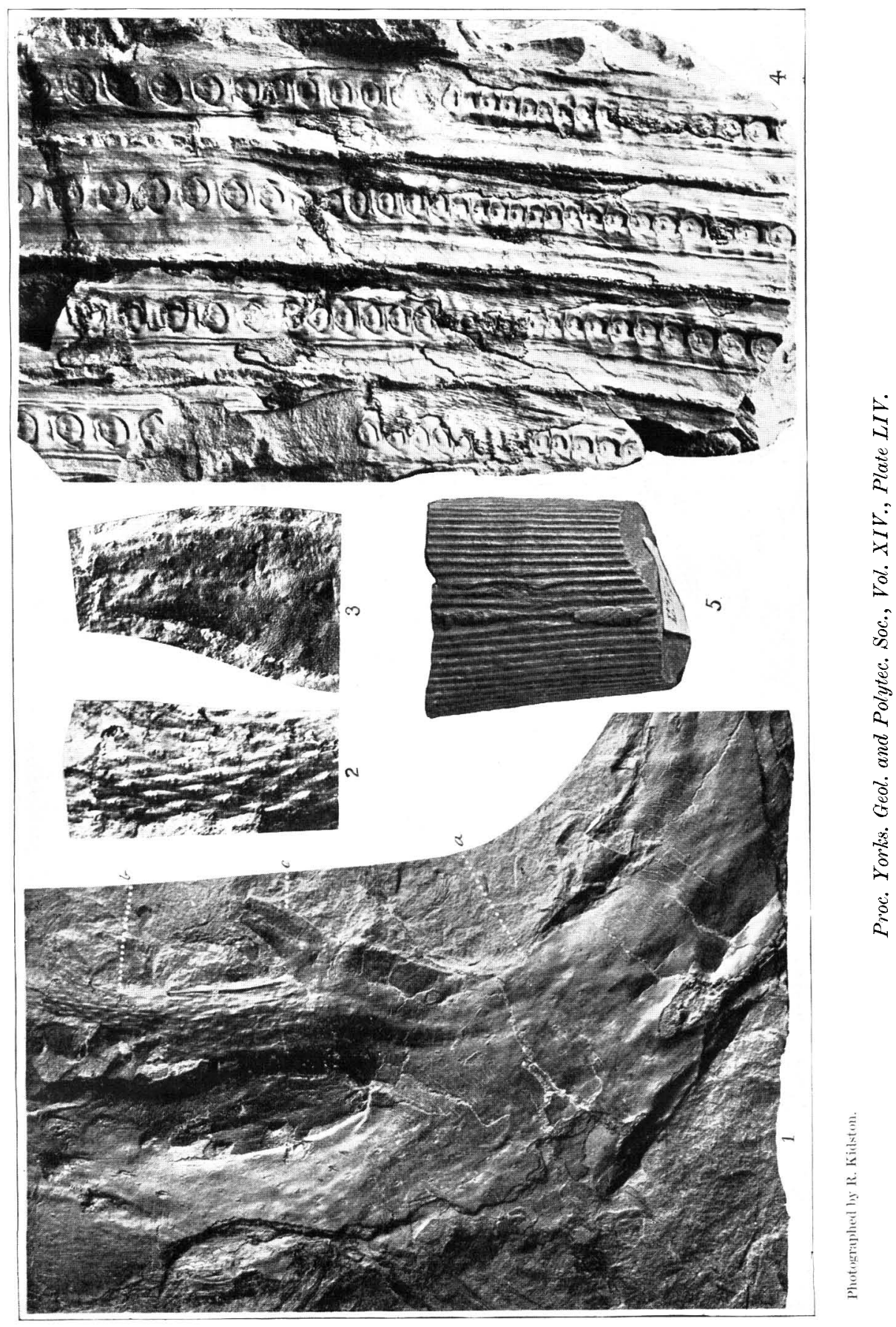


Plate LV.

Fig. 1. Lepidophloios Scoticus Kidston. West Calder, Midlothian. Hor. Oil Shales. Caleiferous Sandstone Series [1798]. Halonial branch showing leaf-scars and spirally-placed scars from which stalked cones have fallen. About onethird natural size.

Fig. 2. Lepidophloios Scoticus Kidston. West Calder, Midlothian. Hor. Oil Shales. Caleiferous Sandstone Series [1810]. Small portion of branch showing leaf-sears and spirally. placed cone scars. About natural size.

Fig. 3. Lepidophloios Scoticus Kidston. Water of Leith, below Canal Bridge, Slateford, Midlothian. Hor. Calciferous Sandstone Series [1822]. Cone attached to its pedicel. About natural size.

Fig. 4. Sigillariostrobus rhombibractiatus Kidston. Monekton Main Colliery, near Barnsley, Yorkshire. Hor. Barnsley Thick Coal. Middle Coal Measures [2263]. Collected by Mr. W. Hemingway. Lower portion of cone attached to its pedicel. About natural size. 


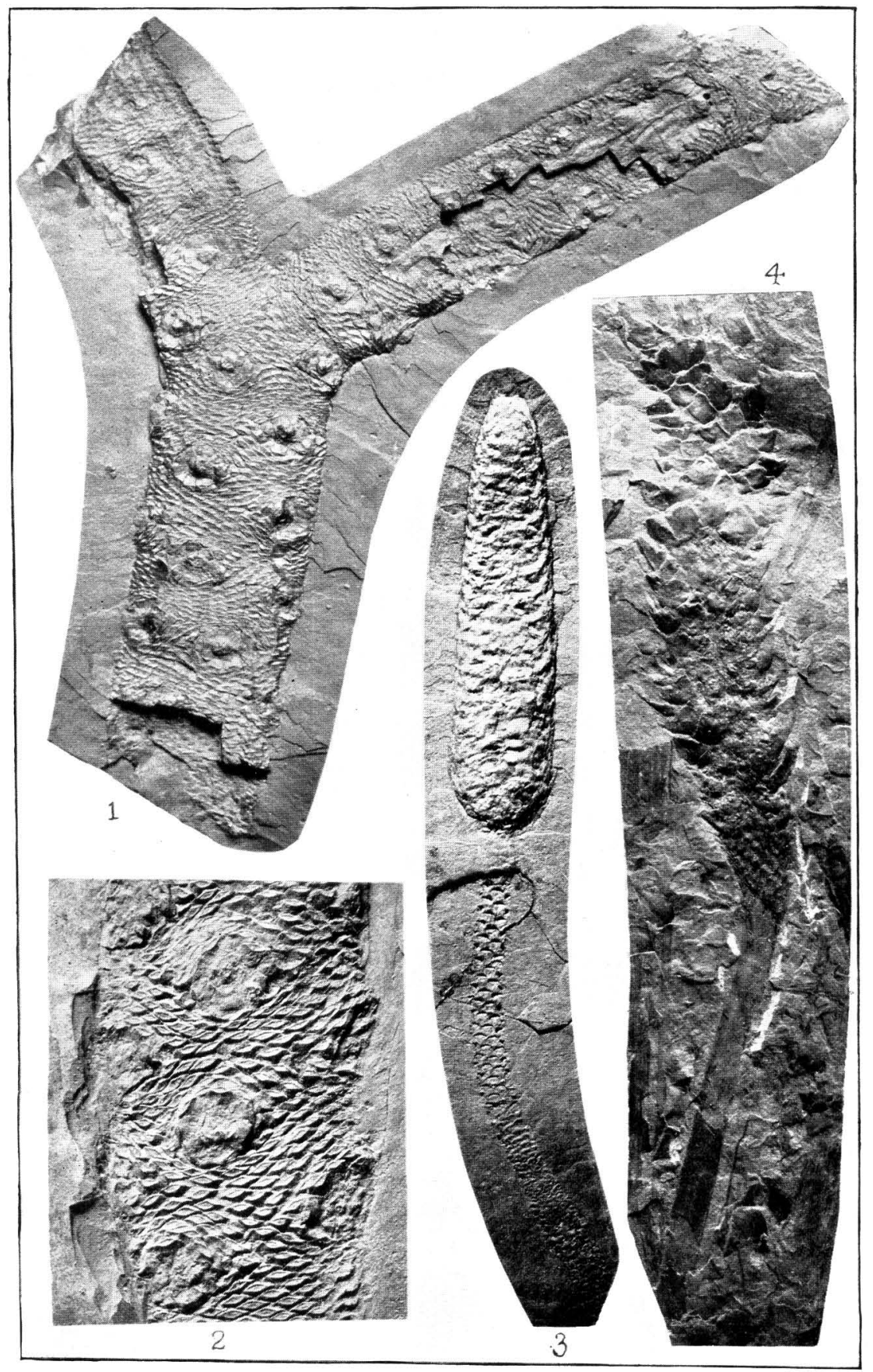

Photogralihed hy R. Kilston

Proc. Yorks. Geol. and Polytec. Soc., Vol. XIV., Plate LV. 


\section{Plate LVI.}

Fig. 1. Lepidodendron Veltheimianum Sternberg. Hailes Quarry, Midlothian. Hor. Calciferous Sandstone Series. Specimen in the collection of the Geological Survey of Scotland, Edinburgh. Illustrating the dichotomous ramification of the genus. Much reduced in size.

Fig. 2. Lepidophloios laricinus Sternberg. Low Moor, Yorkshire. Hor. Black Bed Coal. Middle Coal Measures [1404]. Collected by the late Mr. J. W. Davis, F.G.S. Portion of stem showing cushions and leaf-scars. Three-fifths natural size.

Fig. 3 Stigmaria ficoides Sternberg sp. Watermill Pit, Clackmannan. Hor. Fakes over Cherry Coal. Lower Coal Measures [2545]. Rhizome showing rootlet scars and attached rootlets. Reduced in size. 


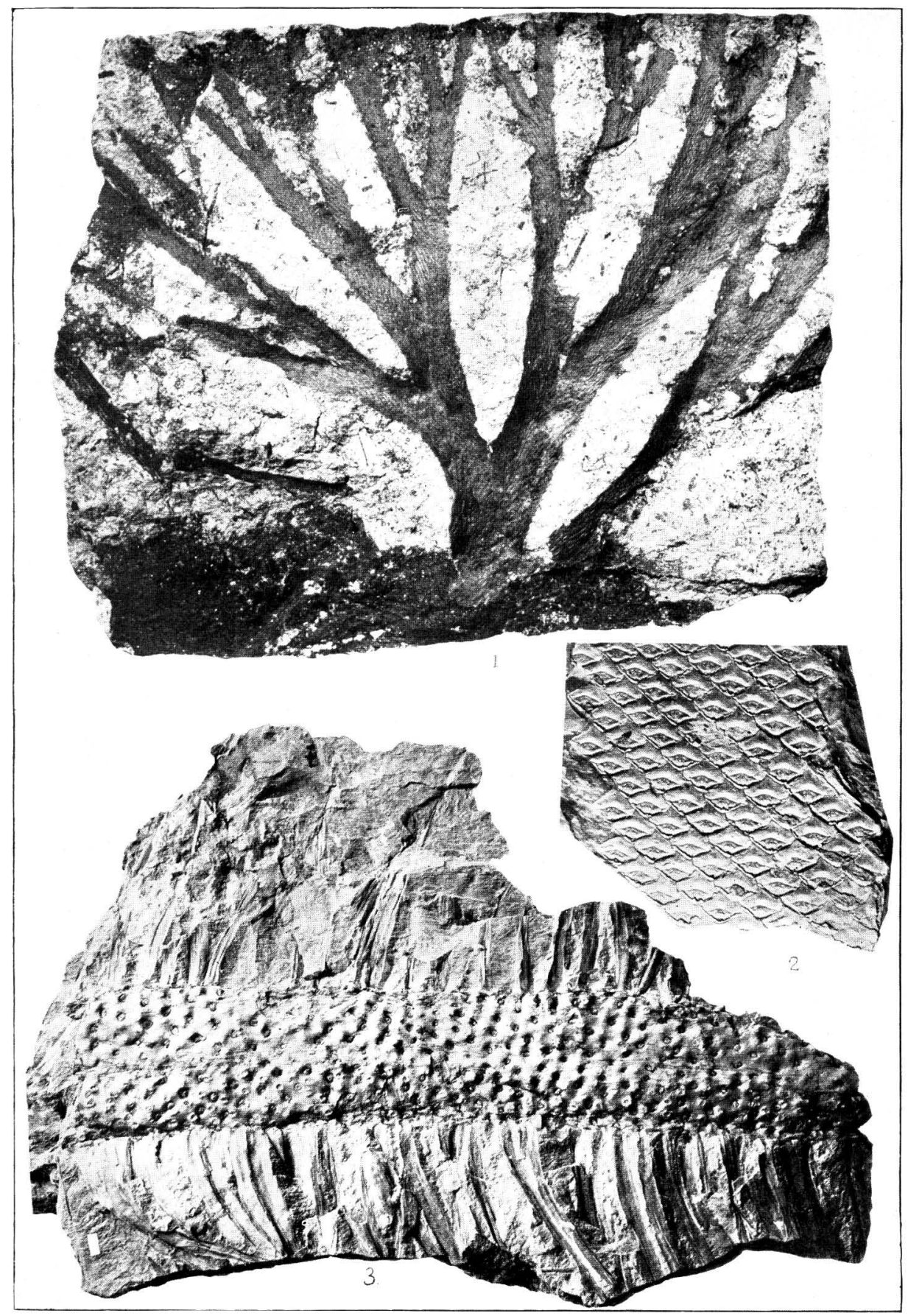

Proc. Yorks. Geol, and Polytec. Soc., Vol. XIV., Plate LVI. 


\section{Plate LVII.}

Fig. 1. Lepidodendron Veltheimianum Sternberg. Shore, Wardie, Midlothian. Hor. Calciferous Sandstone Series [2275]. Collected by Mr. J. A. Johnston. Specimen showing the leaf-scars and four of the cone scars. Two-fifths natural size.

Fig. 2. Cordaites principalis Germar. sp. Monckton Main Colliery, near Barnsley, Yorkshire. Hor. Barnsley Thick Coal. Middle Coal Measures [1478]. Collected by Mr. W. Hemingway. Upper portion of leaf showing blunt apex and parallel nervation. Two-fifths natural size.

Fig. 3. Dorycordaites palmoformis Göpp. sp. Monckton Main Colliery, near Barnsley, Yorkshire. Hor. Barnsley Thick Coal. Middle Coal Measures [2907]. Collected by Mr. W. Hemingway. Complete leaf showing pointed apex. Two-fifths natural size. 


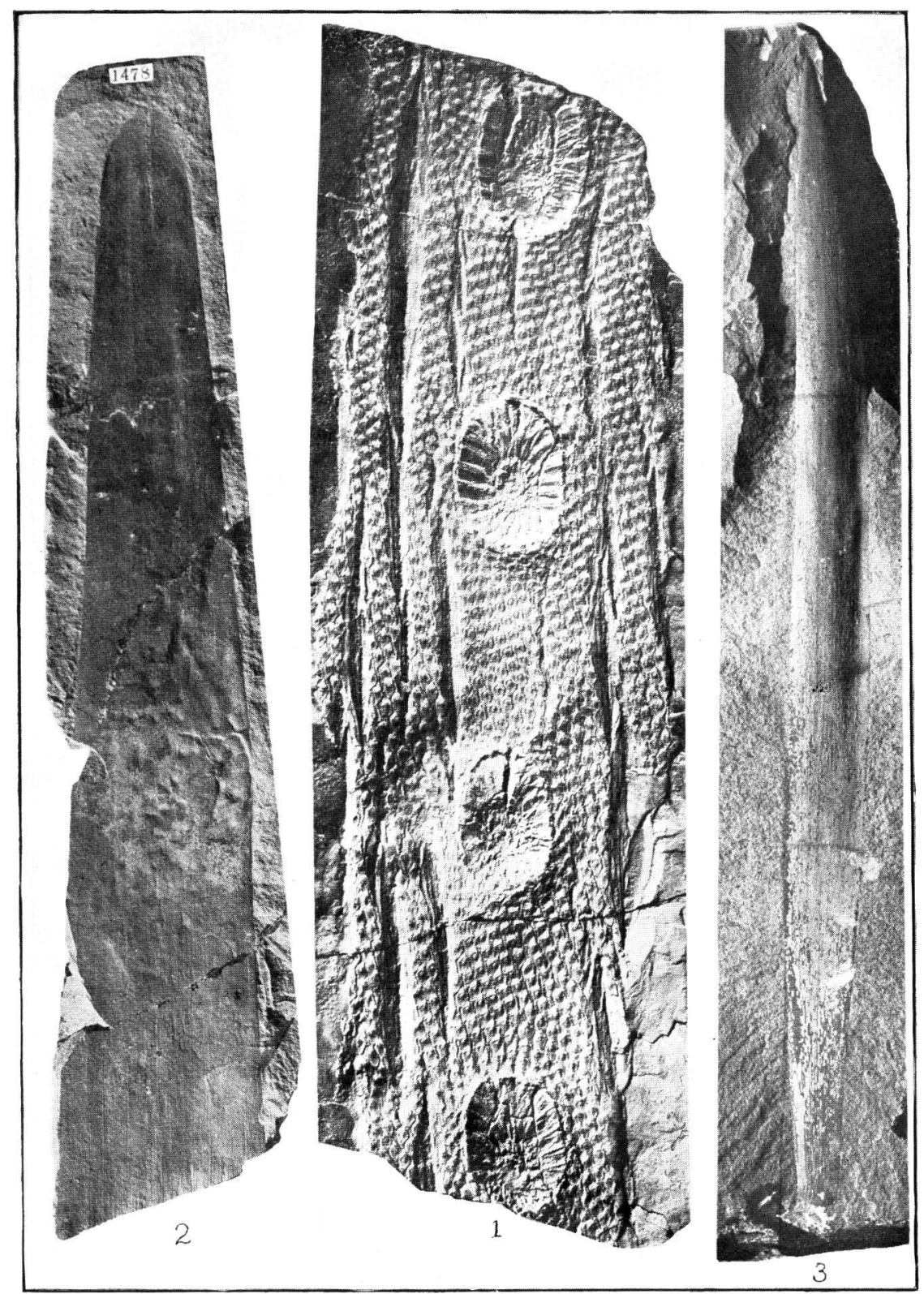

Photographed 1,y R. Killstom.

Proc. Yorks. Geol. and Polytec. Soc., Vol. XIV., Plate LVII. 


\section{Plate LVIII.}

Fig. 1. Sigillaria tessellata Brongt. var. nodosa Bowman sp. Braysdown Colliery, Radstock, Somerset. Hor. Radstock Series. Upper Coal Measures [3024]. Portion of stem showing at $a$ a verticel of cone scars. About natural size.

Fig. 2. Sigillaria Brardii Brongniart. Cope's Marl Pit, Longton, Staffordshire. Hor. Shale above Peacock Coal. Middle Coal Measures [817]. Specimen collected by Mr. John Ward, F.G.S. Portion of a stem showing the cone scars at $a$. About natural size.

Fig. 3. Sigillaria elegans Sternberg sp. Wombwell Main Colliery, near Barnsley, Yorkshire. Hor. Shale over Barnsley Thick Coal. Middle Coal Measures [989]. Speeimen collected by Mr. W. Hemingway. Portion of a specimen showing at $a$ a verticel of cone scars. About natural size.

Fig. 4. Cordaiocarpus Cordai Geinitz sp. Cadeby Colliery, Conisborough, Yorkshire. Hor. Shale on the horizon of the Woolley Edge Rock. Middle Coal Measures [1899]. Collected by Mr. W. Hemingway. About natural size.

Figs. 5 and 6. Samaropsis bicaudata Kidston sp. Long Craig Bay, $1 \frac{1}{2}$ miles west of Dunbar, Haddingtonshire. Hor. Calciferous Sandstone Series [1940 and 1941]. About natural size. 


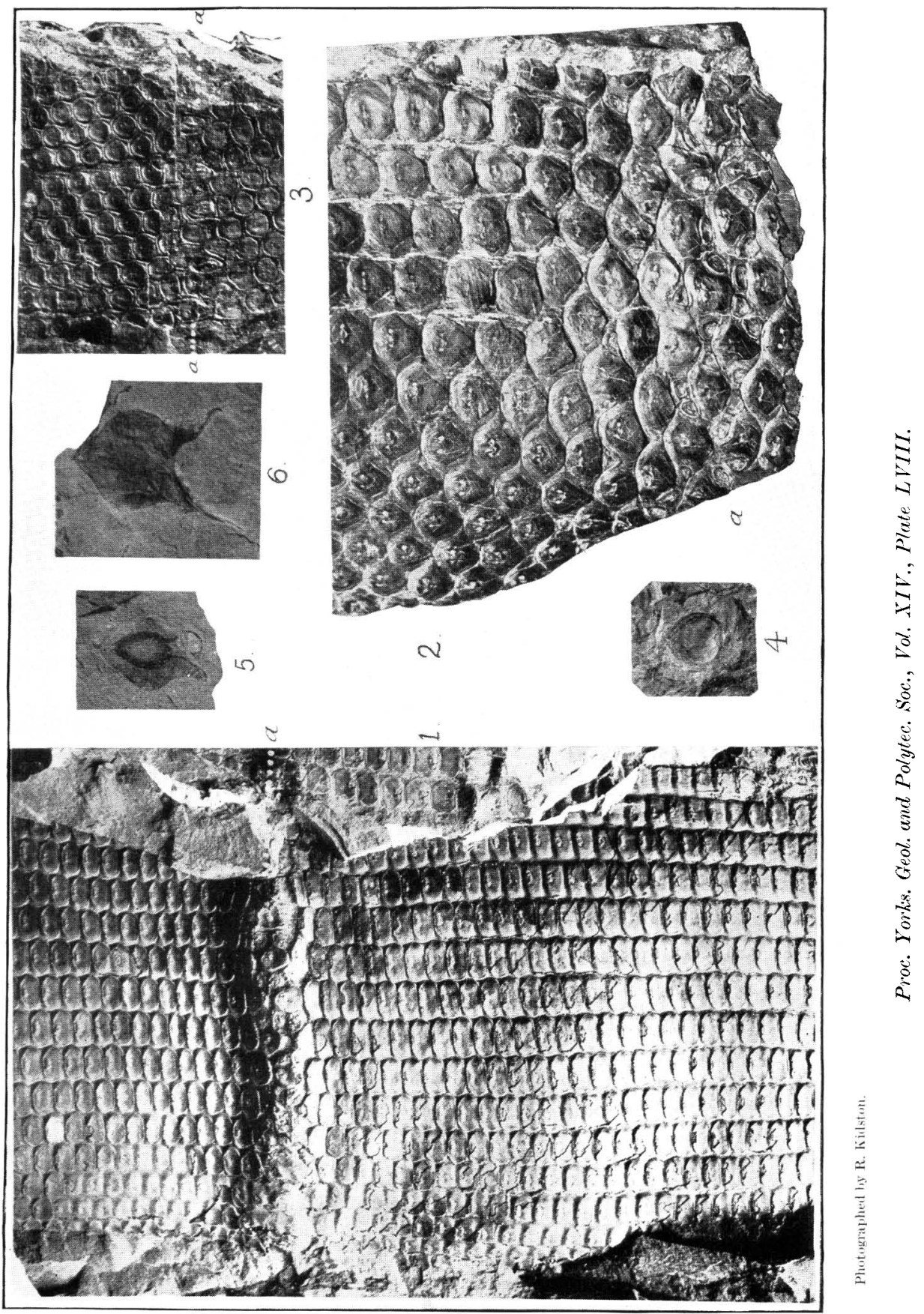




\section{Plate LIX.}

Fig. 1. Sigillaria Brardii Brongniart. Railway Cutting, Florence Colliery, Longton, Staffordshire. Hor. Newcastle-underLyme Group. Upper Transition Series [818]. Collected by Mr. F. Barke, F.G.S. The upper portion of this specimen shows the Sigillaria Brardii Brongt. (section Clathraria) and the lower part Sigillaria denudata Göppert (section Leiodermaria) in organic union. The intermediate portion is the Sigillaria rhomboidea Brongt. About natural size.

Fig. 2. Bothrodendron minutifolium Boulay sp. Monckton Main Colliery, near Barnsley, Yorkshire. Hor. Barnsley Thick. Coal. Middle Coal Measures [1201]. Collected by Mr. W. Hemingway. Branchlet-bearing terminal cone. About natural size. 


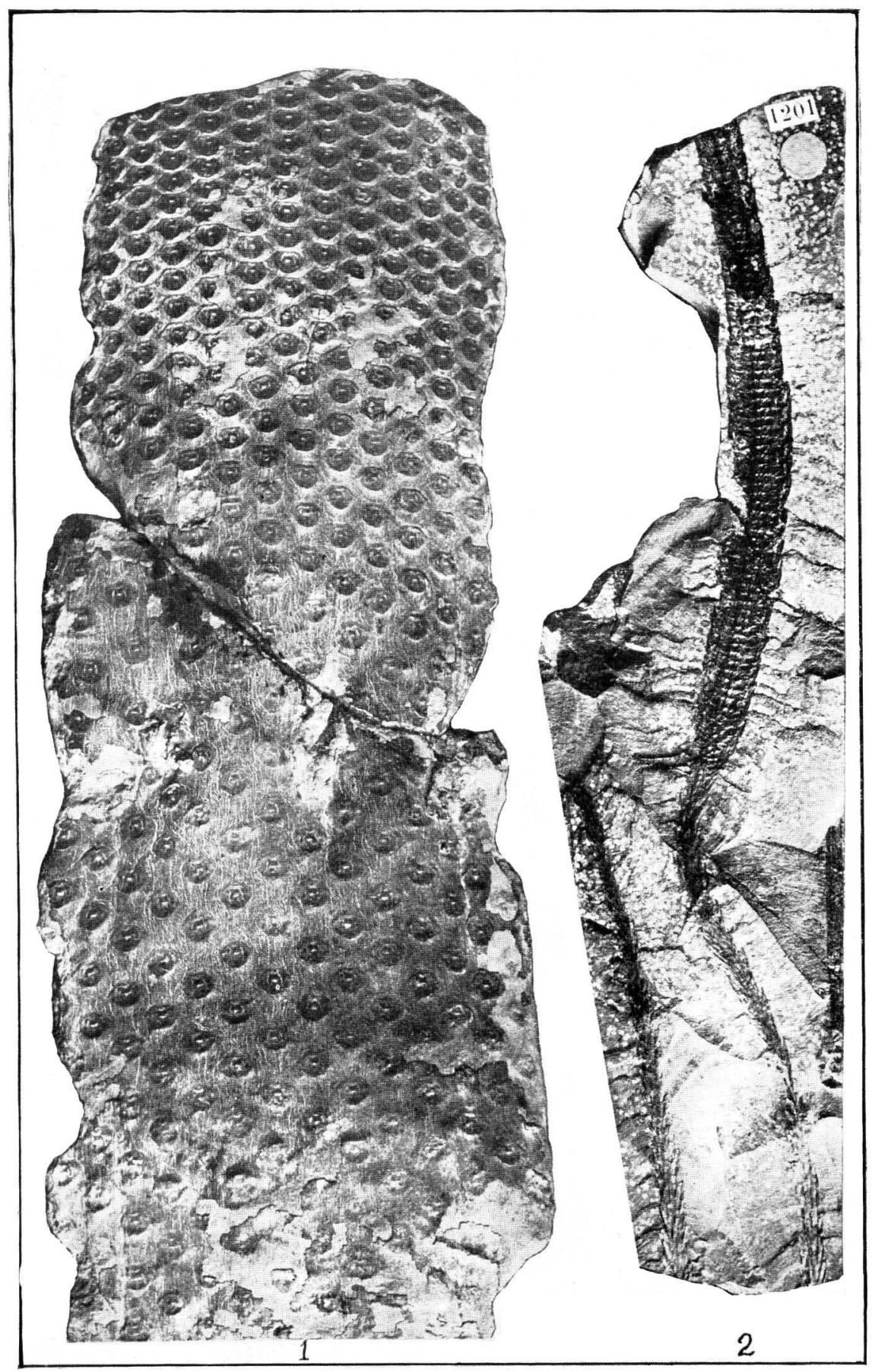

Photegralihed hy R. Kidstom.

Proc. Yorks. Geol. and Polytec. Soe., Vol. XIV., Plate LIX. 
Plate LX.

Fig. 1. Sigillaria discophora König. sp. (=Ulodendron minus L. and H.). Cinderford, Bradley. Coal Measures [2136]. Portion of bark showing leaf-scars and part of one of the two vertical rows of cone sears. About natural size. 


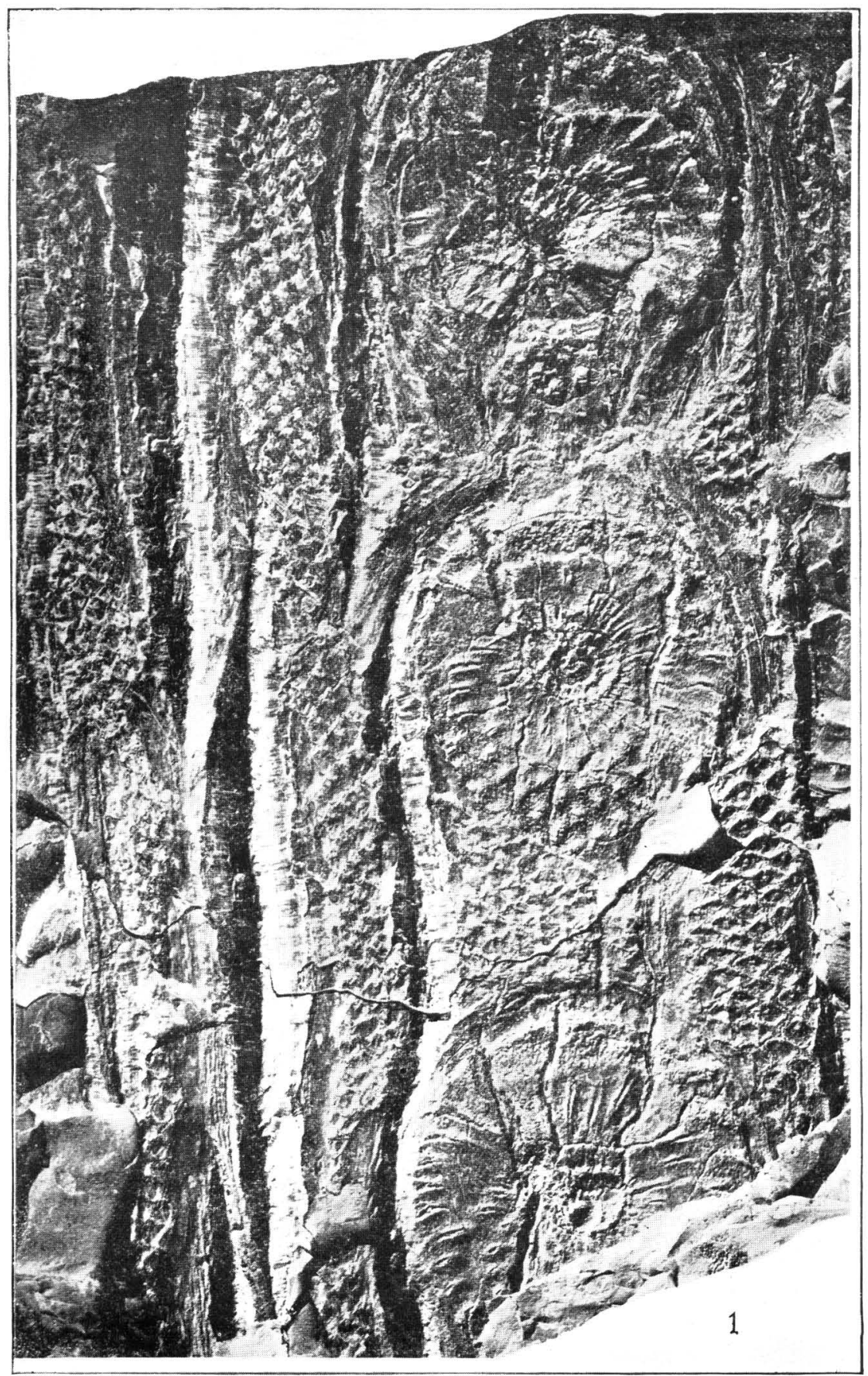

Plotographed hy R. Killston

Proc. Yorke, Geol. and Polytec. Soc., Vol. XIV., Plate LX. 


\section{Plate LXI.}

Fig. 1. Sigillaria rugosa Brongniart. Monckton Main Colliery, near Barnsley, Yorkshire. Hor. Barnsley Thick Coal. Middle Coal Measures [2852]. Collected by Mr. W. Hemingway. Specimen of Rhytidolepis section showing central band of ornamentation. About natural size.

Fig. 2. Sigillaria camptotonia Wood sp. Gelli, Ystrad, Rhondda, Glamorganshire. Hor. No. 2 Rhondda Seam. Upper Transition Series (Lower Pennant Series) [1773]. Collected by Mr. W. O'Connor. Specimen of the Leiodermaria section showing ornamentation of the interfoliar bark. The small scars between the leaf-scars on the upper part of the specimen may be cone scars. About natural size.

Fig. 3. Sigillaria mamillaris Brongniart. Monckton Main Colliery, near Barnsley, Yorkshire. Hor. Barnsley Thick Coal. Middle Coal Measures [2873]. Collected by Mr. W. Hemingway. Specimen of Rhytidolepis section showing leaf-scars on upper portion, and cone and leaf-scars on lower portion. About natural size.

Fig. 4. Rhabdocarpus multistriatus Sternberg sp. Radstock, Somerset. Hor. Radstock Series. Upper Coal Measures [352]. About natural size.

Fig. 5. Cardiocarpus cf. emarginatus Artis sp. Monckton Main Colliery, near Barnsley, Yorkshire. Hor. Barnsley Thick Coal. Middle Coal Measures [1437]. Collected by Mr. W. Hemingway. About natural size. 


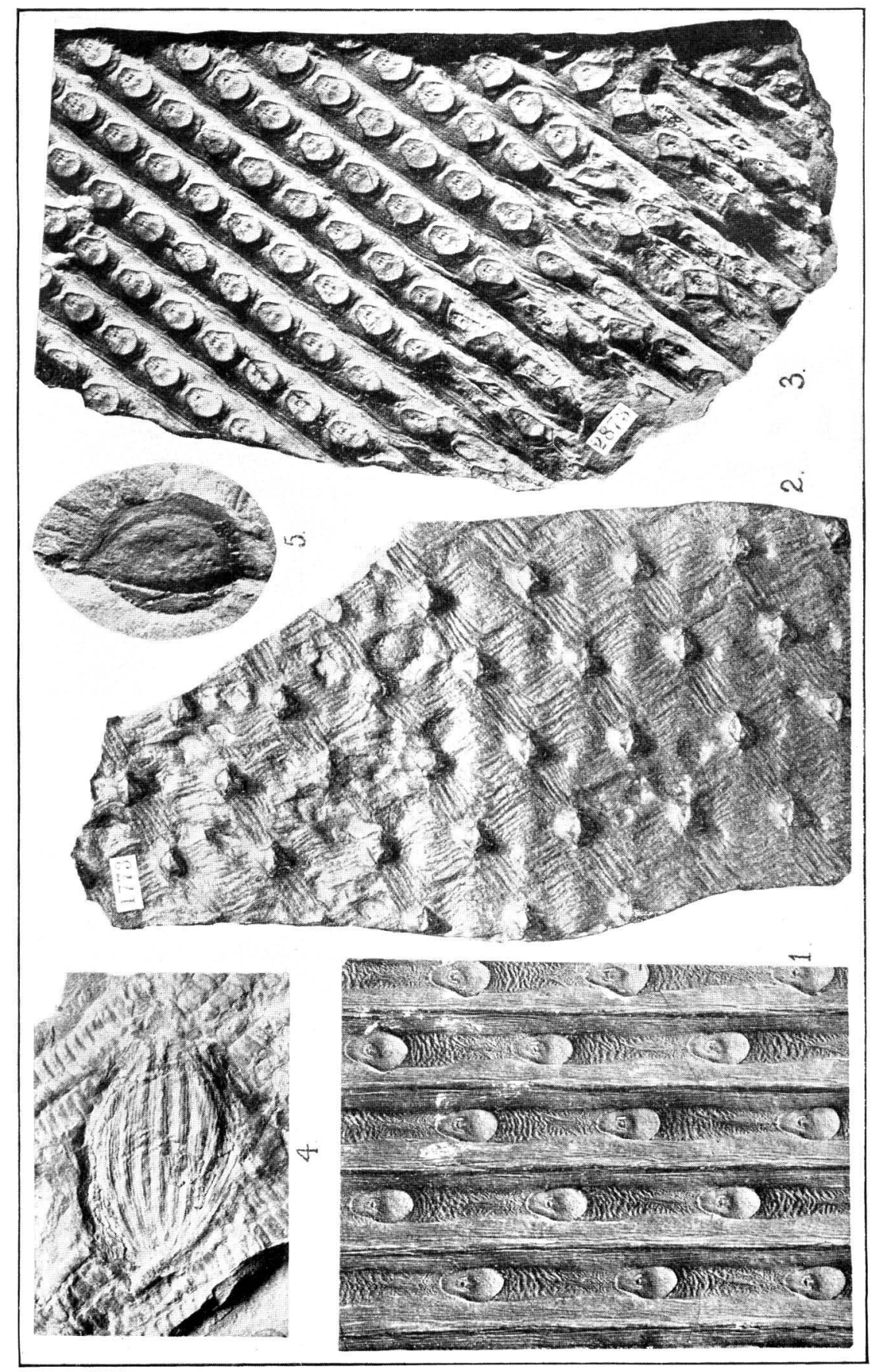




\section{Plate LXII.}

Sphenophyllum majus Bronn. sp. Monckton Main Colliery, near Barnsley, Yorkshire. Hor. Barnsley Thick Coal. Middle Coal Measures [2701]. Collected by Mr. W. Hemingway. $a$ and $b$. Different parts of the same slab. The leaves on fig. $a$ at $a, b, c$, exhibit different degrees of leaf division. About natural size. 


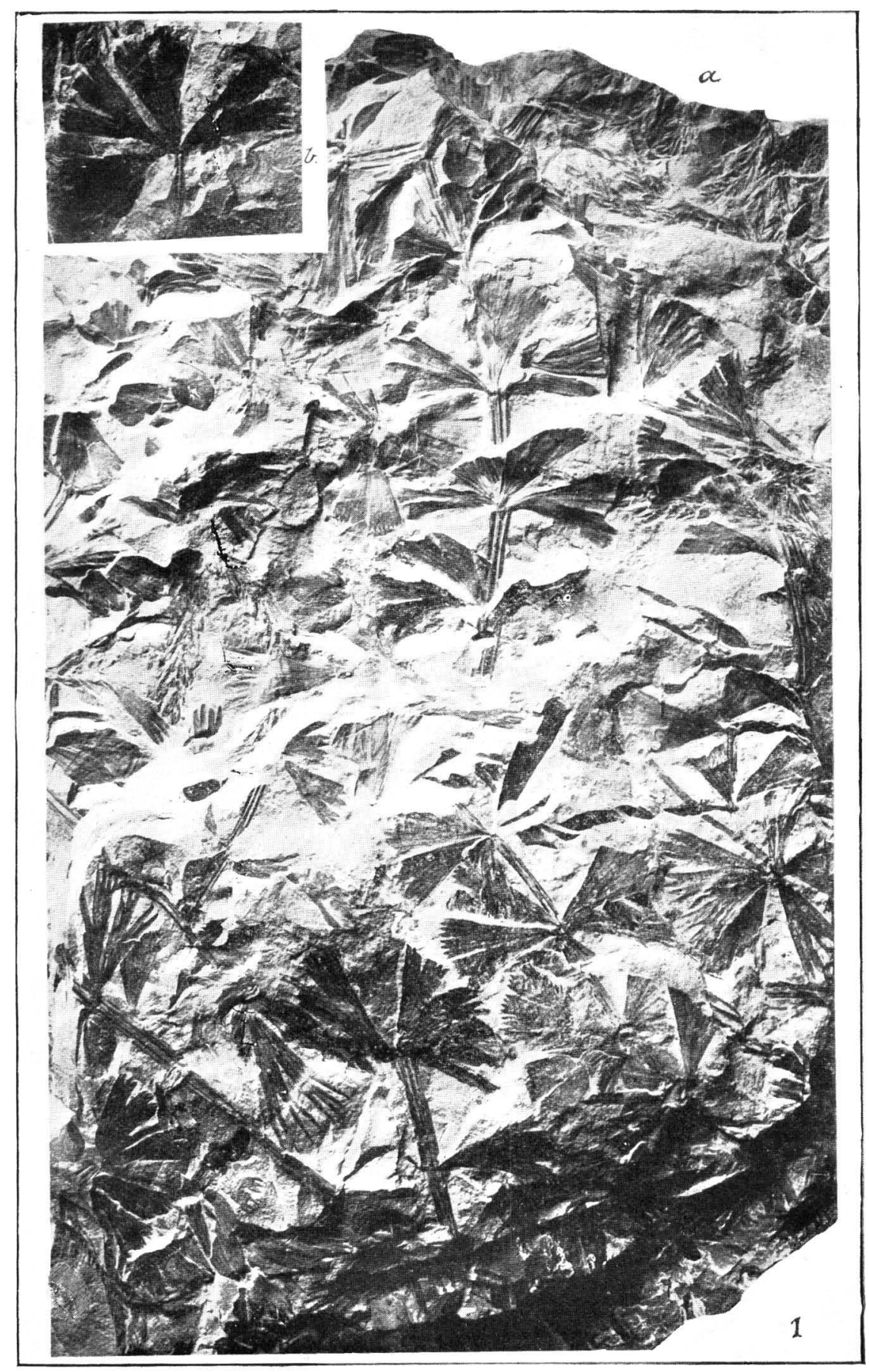

Photographed hy R. Kitlst m.

Proc. Yorks. Geol. and Polytec. Soc., Vol. XIV., Plate LXII. 


\section{Plate LXIII.}

Fig. 1. Walchia imbricata Schimper. From shaft of Hamstead Colliery, Great Barr, Staffordshire. Hor. At depth of 350 feet from surface. Upper Coal Measures. About natural size (see Trans. Roy. Soc. Edin., Vol. XXXV., Part 6, page 324).

Fig. 2. Sphenophyllum myriophyllum Crépin. Oaks Colliery, Barnsley, Yorkshire. Hor. Woolley Edge Rock. Middle Coal Measures [2206]. Collected by Mr. W. Hemingway. Specimen showing jointed and ribbed stem and lateral branch. About natural size. 


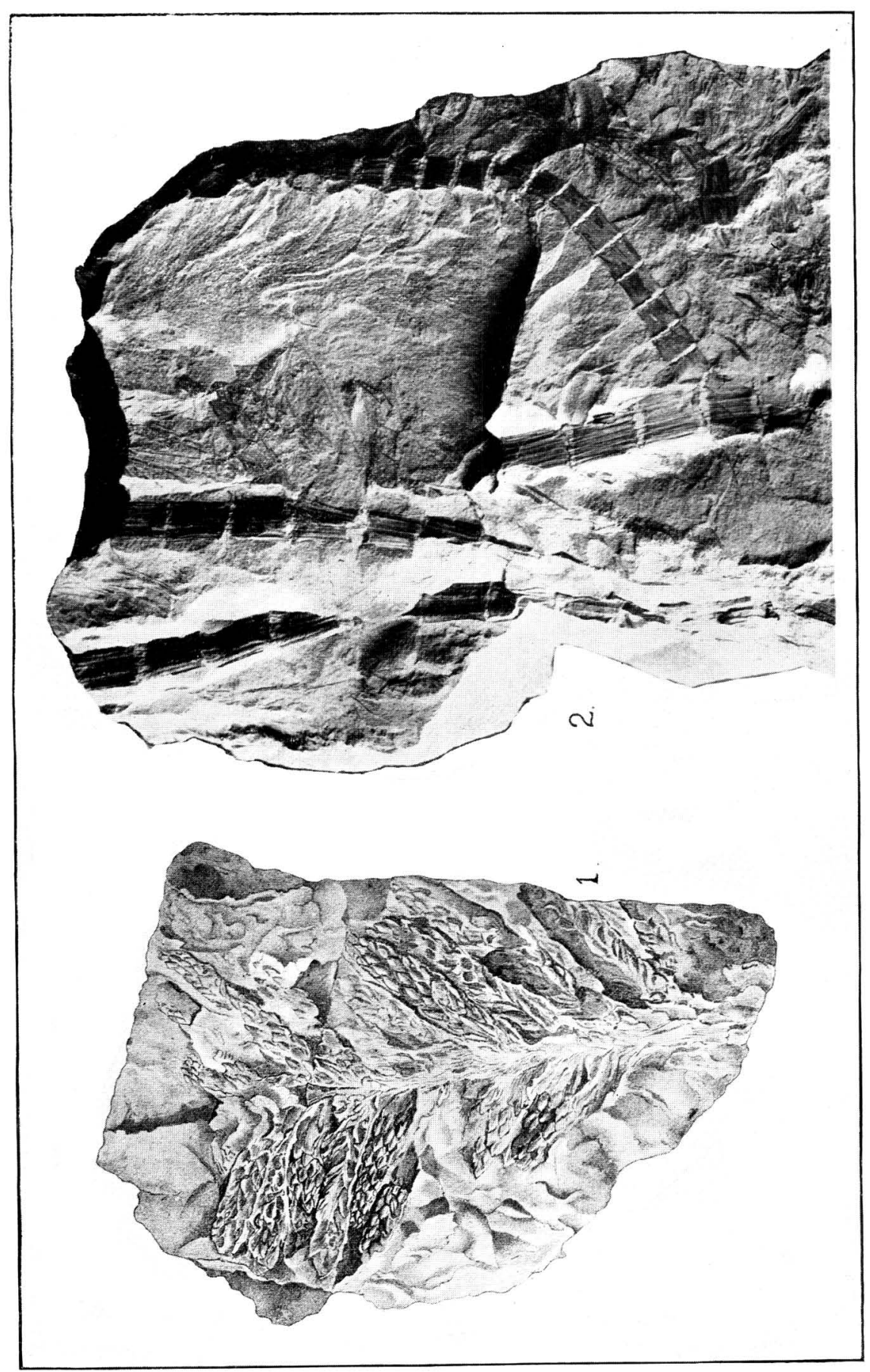

 


\section{Plate LXIY.}

Fig. 1. Lycopodites Gutbieri Göppert. Camerton, Somerset. Hor. Radstock Series. Upper Coal Measures [1501]. Collected by Mr. W. Hemingway. About natural size.

Fig. 2. Poacordaites microstachys Goldenberg sp. Camerton, Somerset. Hor. Radstock Series. Upper Coal Measures [3022]. Small stem showing leaves attached. About natural size.

Fig. 3. Cordaites principalis Germar. sp. Monckton Main Colliery, near Barnsley, Yorkshire. Hor. Barnsley Thick Coal. Middle Coal Measures [1479]. Collected by Mr. W. Hemingway. Between the letters $a$ and $a$ is seen the row of small cicatrices of the vascular strands which enter the leaf. About natural size.

Fig. 4. Omphalophloios anglicus Sternberg sp. Camerton, Somerset. Hor. Radstock Series. Upper Coal Measures [433]. Collected by Mr. G. West. Portion of specimen showing the scars placed in rhomboidal areas. Note- - Owing to the direction in which the light has struck the specimen the rhomboidal areas are not so distinctly seen as they would be were the light coming from a different direction. The rhomboidal character of the area is, however, well seen at $a$. About natural size. 


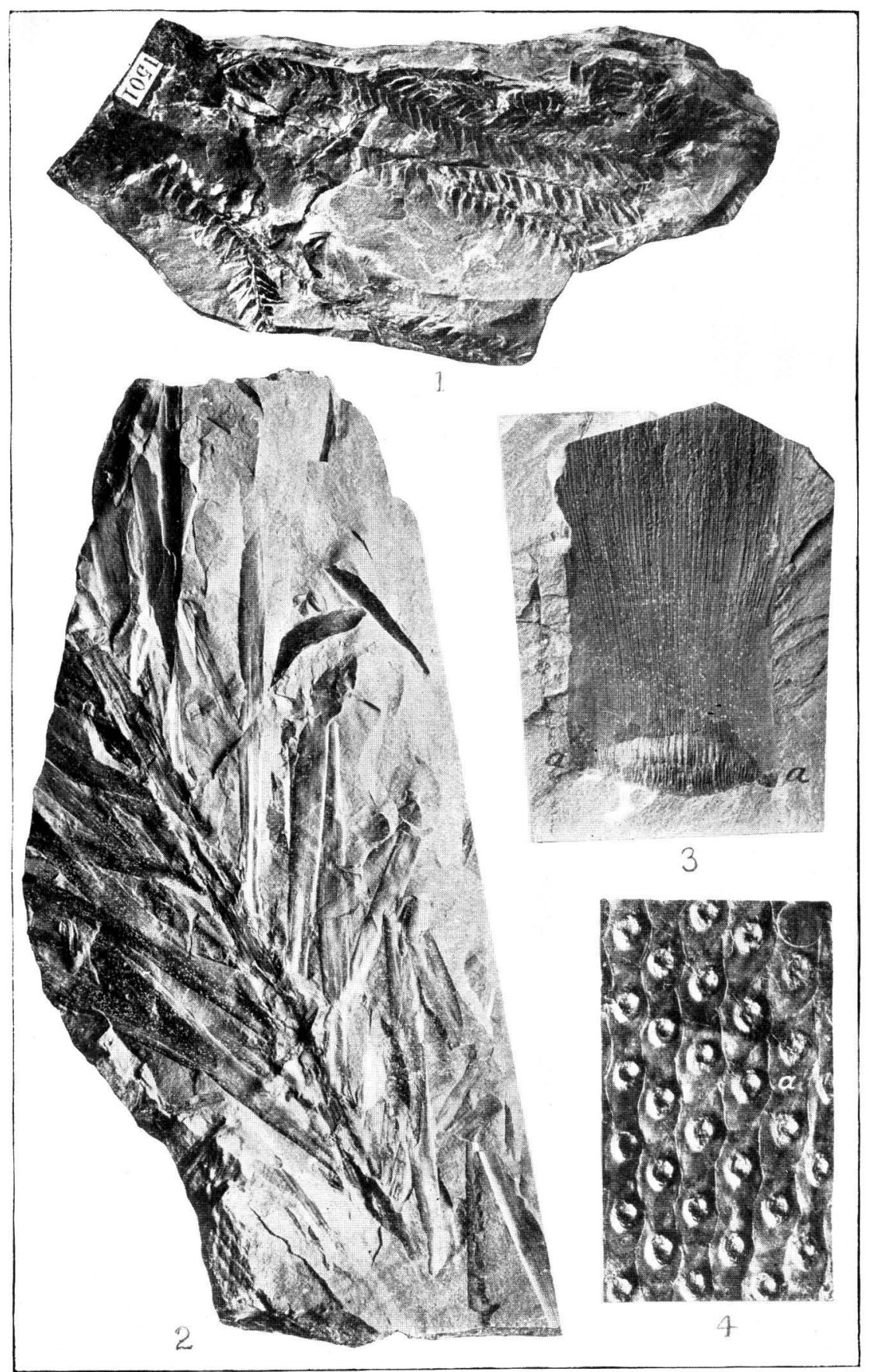

Photegrapited hy R. Kidsten.

Proc. Yorks, Geol. and Polytec. Soc., Vol. XIV., Plate LXIV. 


\section{Plate LXV.}

Fig. 1. Trigonocarpus Parkinsoni Brongniart. Bonnington Pit, Kilmarnock, Ayrshire. Hor. Whistler Seam. Lower Coal Measures [1580]. Specimen received from the Rev. D. Landsburgh, D.D., showing nut enclosed in its pericarp. In this condition the fossil is the Carpolithes alata L. and H. About natural size.

Fig. 2. Trigonocarpus Parkinsoni Brongniart. Bonnington Pit, Kilmarnock, Ayrshire. Hor. Whistler Seam. Lower Coal Measures [591]. Specimen received from the Rev. D. Landsburgh, D.D. This example, though not so far developed as that shown at Fig. 1, exhibits the enclosed nut more clearly. About natural size.

Fig. 3. Trigonocarpus Parkinsoni Brongniart. Peel Quarry, near Bolton, Lancashire. Middle Coal Measures. Collected by Mr. R. Law. $a$ [2656], $b$ [2663] side views. $c$ [2658], base of nut showing point of attachment. About natural size.

Fig. 4. Carpolithes perpusillus Lesquereux. Pit near Kirkwood, Lanarkshire. Lower Coal Measures [163 and 164]. Collected by Mr. R. Dunlop. About natural size.

Fig. 5. Cordaianthus with Samaropsis fluitans Dawson. Monckton Main Colliery, near Barnsley, Yorkshire. Hor. Barnsley Thick Coal. Middle Coal Measures [2374]. Collected by Mr. W. Hemingway. The Samaropsis fluitans Dawson, one of which is seen at $a$, are probably the seeds of the Cordaianthus with which they occur. About natural size.

Fig. 6. Artisia transversa Artis sp. Brierley Tunnel, near Barnsley. Yorkshire. Hor. Houghton Common Rock. Middle Coal Measures [1261]. Collected by Mr. W. Hemingway. The pith east of Cordaites. About natural size. 


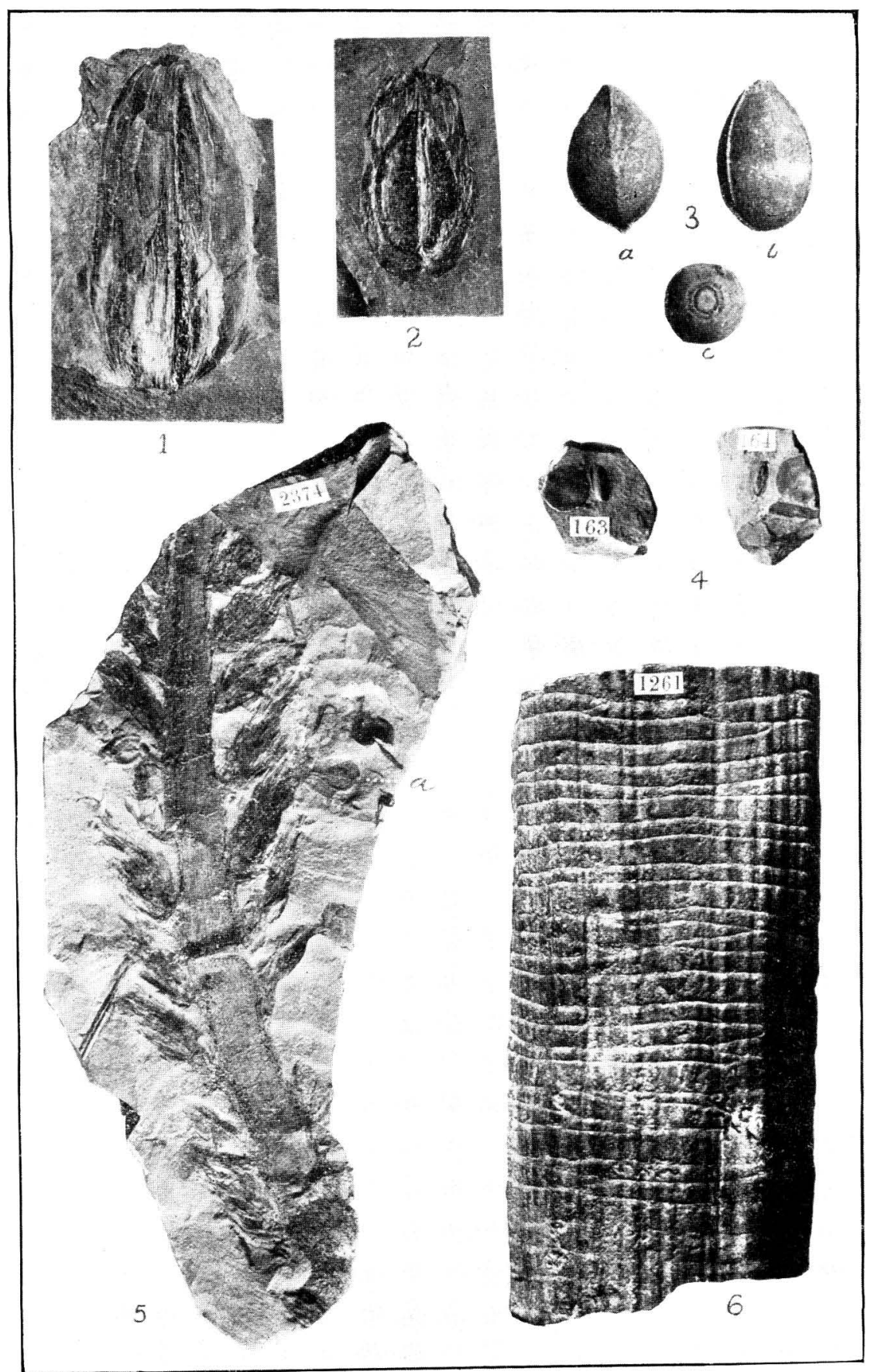

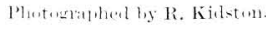

Proc. Yorks. Geol. and Polytec. Soc., Vol. XIV., Plate LXV. 